\title{
Revision of the Swedish species of Neoxorides Clément, 1938 (Ichneumonidae: Poemeniinae) with the description of a new species and an illustrated key to species
}

\author{
Niklas JOHANSSON $^{1, *}$ \& Seraina KLOPFSTEIN ${ }^{2}$ \\ ${ }^{1}$ Baskarp Fredriksberg 1, 56692 Habo, Sweden. \\ ${ }^{2}$ Naturhistorisches Museum Basel, Augustinergasse 2, CH-4001 Basel, Switzerland. \\ *Corresponding author: chrysis32@yahoo.se \\ ${ }^{2}$ Email: seraina.klopfstein@bs.ch \\ ${ }^{1}$ urn:1sid:zoobank.org:author:B0031F47-99F7-4FEE-B545-B6F1E79E1A4E \\ ${ }^{2}$ urn:1sid:zoobank.org:author:4F22C48F-2D0E-4554-95C9-01D2635E3146
}

\begin{abstract}
Neoxorides Clément, 1938 is a small genus of ichneumonid wasps that develop on woodboring beetles. We here revise the Western Palaearctic species of the genus, with a special focus on Sweden. A new species, N. striatus Johansson sp. nov. is described. Neoxorides opacus (Kokujev, 1903) stat. rev. is excluded from the synonymy with $N$. nitens (Gravenhorst, 1829) and reinstated as a valid species. The species is redescribed from European material. Neoxorides kissi (Ulbricht, 1911) is confirmed as a junior synonym of $N$. opacus. A neotype for $N$. opacus is designated. New characters to distinguish $N$. varipes (Holmgren, 1860), N. collaris (Gravenhorst, 1829) and N. montanus Oehlke, 1966 are presented. Almost all of the species treated are supported by DNA-barcoding. An illustrated key to the species occurring in the Western Palaearctic is provided, a prerequisite for making the genus accessible for future ecological and conservation studies.
\end{abstract}

Keywords. Saproxylic, molecular, new species, review, barcoding.

Johansson N. \& Klopfstein S. 2020. Revision of the Swedish species of Neoxorides Clément, 1938 (Ichneumonidae: Poemeniinae) with the description of a new species and an illustrated key to species. European Journal of Taxonomy 680: 1-29. https://doi.org/10.5852/ejt.2020.680

\section{Introduction}

Our knowledge of species diversity in insects is still embarrassingly incomplete, even in relatively well-known regions such as Europe. A large inventory based on millions of insect specimens from the Swedish Malaise Trap Project (SMPT) recently concluded that the largest gaps in our knowledge are among dipteran decomposers and hymenopteran parasitoids (Ronquist et al. 2020), such as Ichneumonidae Latreille, 1802 (also called "Darwin wasps" since recently: Klopfstein et al. 2019). Even small and easily recognized genera still hold undetected diversity, if examined carefully. We here revise the Western Palaearctic species of Neoxorides Clément, 1938, using a combination of morphological and molecular data. 
Neoxorides belongs to the ichneumonid subfamily Poemeniinae Narayanan \& Lal, 1953. It is a small Holarctic genus currently comprising 10 described species worldwide (Yu et al. 2016). The species are assumed to be idiobiont ectoparasitoids of various xylophagous Coleoptera Linnaeus, 1758, primarily Cerambycidae Latreille, 1802 and Buprestidae Leach, 1815 (Broad et al. 2018). It shall hereby be noted that there are many unreliable host associations in the literature, where specimens of Neoxorides have been reared from wood containing multiple species of Coleoptera as well as hole-nesting aculeates (Broad et al. 2018). The Western Palaearctic species were revised by Oehlke (1966), who recognized four species: Neoxorides nitens (Gravenhorst, 1829), N. collaris (Gravenhorst, 1829), N. varipes (Holmgren, 1860) and $N$. montanus Oehlke, 1966. The fauna of North America was revised by Townes et al. (1960) and the Oriental fauna has partly been treated by Uchida (1928) and Sheng (1998). Kanders (2009), revised the Swedish species of Poemeniinae, including Neoxorides, in a Master's degree project at Uppsala University. However, the study only recognized two species, Neoxorides collaris and N. varipes.

The genus Neoxorides in the Western Palaearctic is distinguished from all but one similar genera by the elongate and slender legs and body (Figs 1A, 8B), the relatively long ovipositor in the female and the coarsely sculptured temples, which have a scale-like structure (Fig. 1B). These features are also found in the closely related genus Podoschistus Townes, 1957, which has the tergites distinctly and densely punctate, in contrast to the smoother and finely shagreened tergites in Neoxorides.

This paper reviews the Swedish species of Neoxorides. Six species are recognized and revised taxonomically using morphological and molecular methods.

\section{Material and methods}

\section{Specimen base and morphological analyses}

About 150 specimens of Neoxorides in private and public collections in Sweden and to some extent other countries, as well as relevant type material, were studied and sorted out by the first author. Some of the studied specimens were then barcoded by the second author to support the conclusions presented by the morphological and taxonomical analysis (see below). The material collected by the Swedish Malaise Trap Project seems to be lost (Dave Karlsson, SMTP, pers. comm.), but has been treated partly by Kanders (2009) and Olexandr Varga (unpublished data; Dave Karlsson, SMTP, pers. comm.). Since none of these authors were aware of the true diversity of the genus in Sweden, these records are not relisted.

Morphological terminology follows Broad et al. (2018). Fore wing length is measured as the greatest distance from the apex of the tegula to the wing tip. Unless stated otherwise, close up photos were taken by Alexander Berg with a Canon EOS 6D with a reversed tube lens-Thorlabs ITL200 with either a Schneider Kreuznach Componon $28 \mathrm{~mm}$ f4 or a Schneider Kreuznach Componon-S $50 \mathrm{~mm}$ f2.8 and then stacked with Zerene Stacker. Geographical regions with abbreviations are depicted in Fig. 2.

\section{Depositories (corresponding curator/ contact)}

\begin{tabular}{|c|c|c|}
\hline HNHM & $=$ & Hungarian Natural History Museum, Budapest, Hungary (Zoltán Vas) \\
\hline JA & $=$ & Collection of Johan Abenius, Nynäshamn, Sweden (Johan Abenius) \\
\hline $\mathrm{JH}$ & $=$ & Collection of Jacek Hilszczański, Forest Research Institute, Poland (Jacek Hilszczański) \\
\hline LW & $=$ & Collection of Lars-Ove Wikars, Borlänge, Sweden (Lars-Ove Wikars) \\
\hline MNHN & $=$ & Muséum national d'histoire naturelle Paris, France (Claire Villement) \\
\hline MR & $=$ & Collection of Matthias Riedel, Bad Fallingbostel, Germany (Matthias Riedel) \\
\hline $\mathrm{MZH}$ & $=$ & Finnish Museum of Natural History, Helsinki, Finland (Juho Paukkunen) \\
\hline MZLU & $=$ & Zoologiska Museet, Lunds Universitet, Lund, Sweden (Rune Bygebjerg) \\
\hline NHMUK & $=$ & Natural History Museum, London, United Kingdom (Gavin Broad) \\
\hline
\end{tabular}



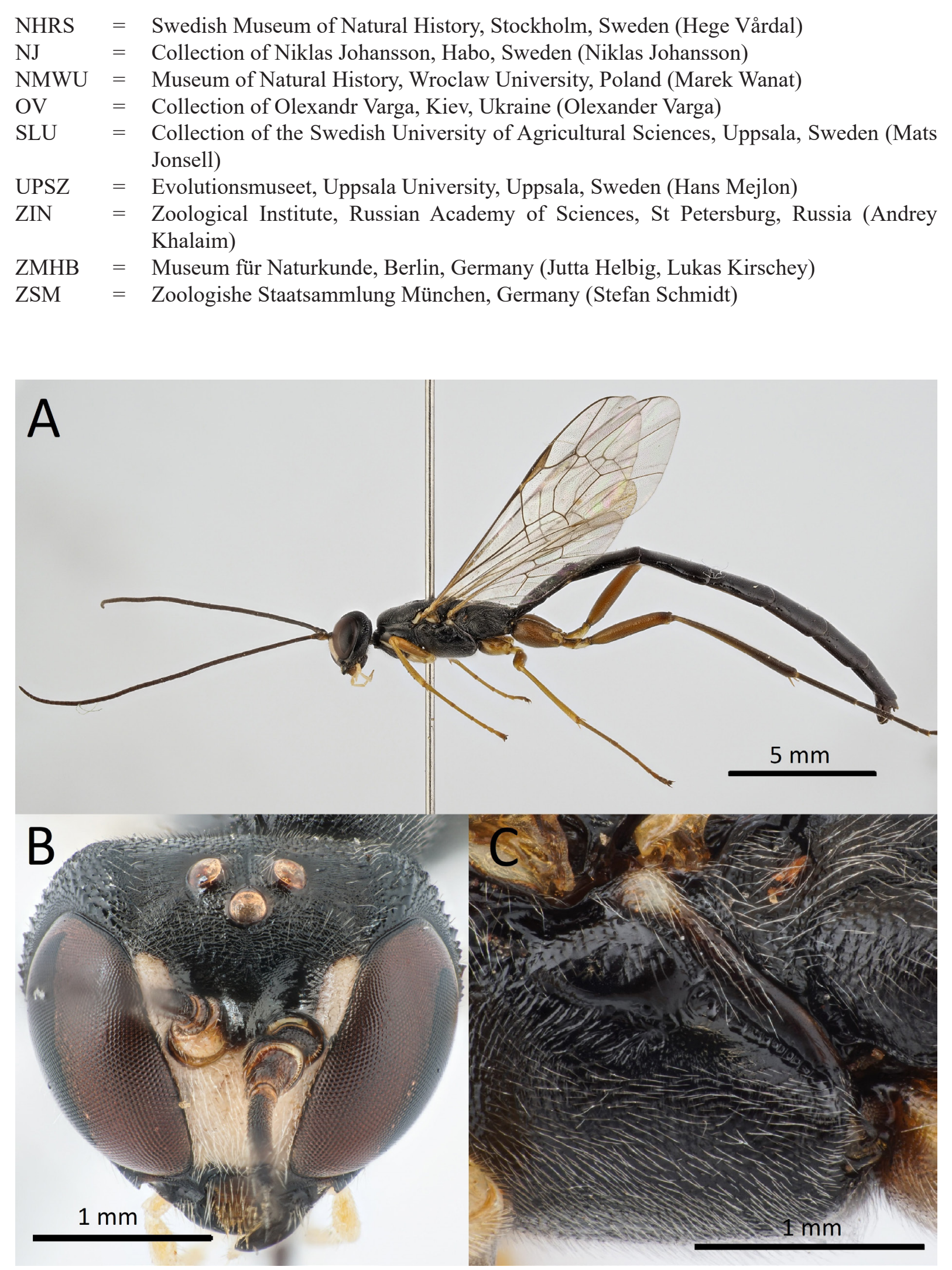

Fig. 1. Neoxorides striatus Johansson sp. nov., holotype đิ (BC ZSM HYM07485). A. Habitus, lateral view. B. Head, anterior view. C. Mesopleuron, lateral view. Photos: Stefan Schmidt. 


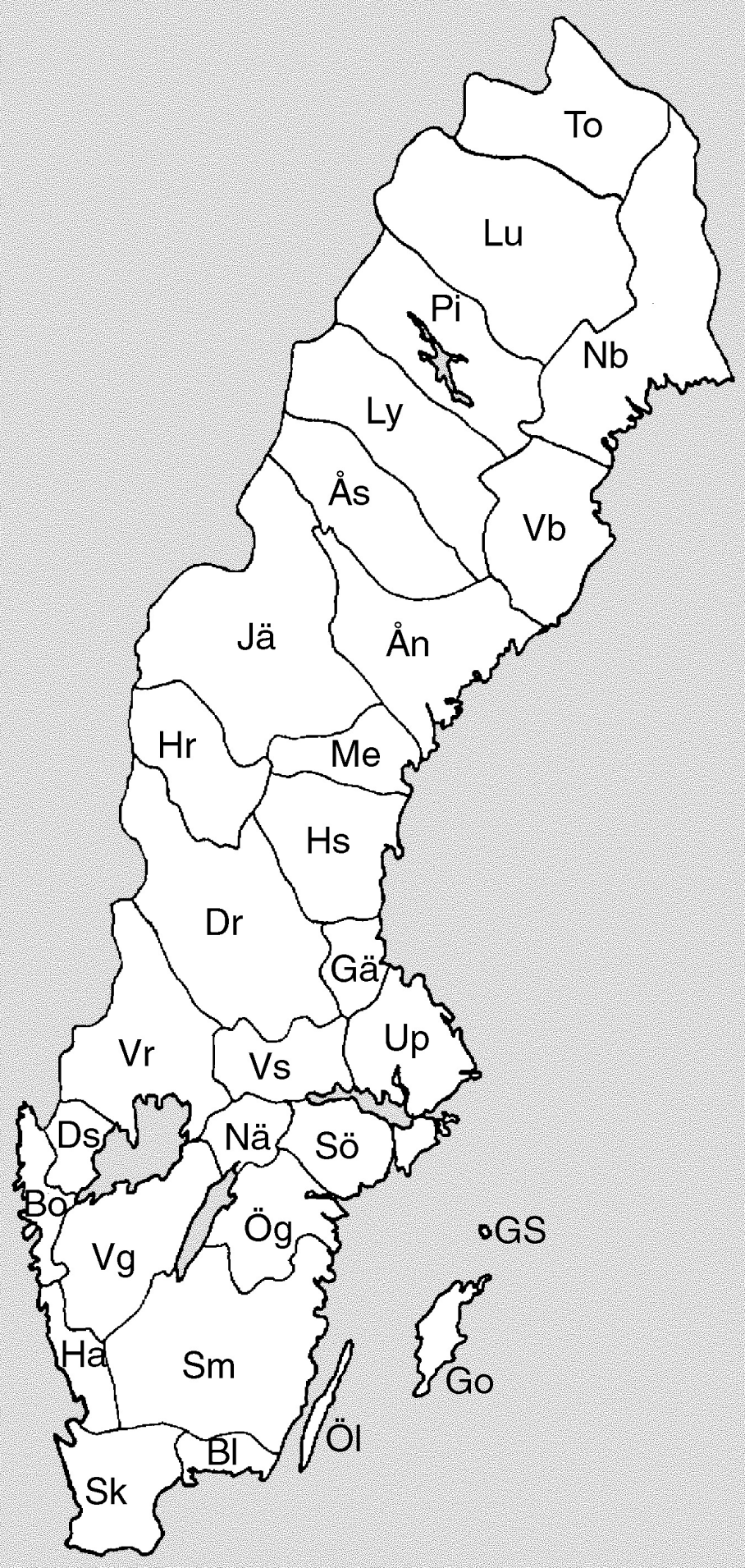

Fig. 2. Map of Sweden with borders and used abbreviations of the faunistic provinces from south to north: Sk = Skåne, Bl = Blekinge, Ha = Halland, Sm = Småland, Öl = Öland, Go = Gotland, Ög = Östergötland, Vg = Västergötland, Bo = Bohuslän, Ds = Dalsland, Nä = Närke, Sö = Södermanland, Up = Uppland, Vs $=$ Västmanland, $\mathrm{Vr}=$ Värmland, $\mathrm{Dr}=$ Dalarna, $\mathrm{Gä}=$ Gästrikland, $\mathrm{Hs}=$ Hälsingland, $\mathrm{Me}=$ Medelpad, $\mathrm{Hr}=$ Härjedalen, Jä = Jämtland, Ån = Ångermanland, $\mathrm{Vb}=$ Västerbotten, $\mathrm{Nb}=$ Norrbotten, Ås = Åsele lappmark, $\mathrm{Ly}=$ Lycksele lappmark, $\mathrm{Pi}=$ Pite lappmark, $\mathrm{Lu}=$ Lule lappmark, $\mathrm{To}=$ Torne lappmark. 


\section{DNA extraction}

One to four specimens of $N$. collaris, $N$. montanus and $N$. opacus (Kokujev, 1903) were subjected to molecular analysis. Extractions were unsuccessful for $N$. varipes, for which no suitable material was available. Additional barcodes for N. striatus Johansson sp. nov., N. nitens and the North American $N$. caryae (Harrington, 1891), as well as a sequence of Podoschistus vittifrons (Cresson, 1868) to be used as an outgroup, were obtained from GenBank and from the Barcoding Fauna-Bavarica project.

DNA was extracted from mid or hind legs using the Qiagen DNeasy Blood \& Tissue kits according to the manufacturer's instructions, but allowing 16-18 hours for the digestion step. We then first tried to amplify $\sim 700 \mathrm{bp}$ of the $5^{\prime}$ half of $\mathrm{CO} 1$ (barcoding region) using primers from Folmer et al. (1994) (forward: LCO 5'-GGTCAACAAATCATAAAGATATTGG-3'; reverse: HCO 5'-TAAACTTCAGGGTGACCAAAAAATCA-3'). If that failed, we used two newly developed primers for ichneumonid wasps to PCR the marker in two parts. The new reverse primer (SK-RA435: 5'-GCTCCTATAATAGAAGATATACCAGC-3') amplifies about 460 bp when combined with LCO, while the new forward primer (SK-FA336: 5'-CAAGGTGTTGGTACTGGATGAAC-3') resulted in about $374 \mathrm{bp}$ when combined with HCO. If sequenced in both directions, the shorter stretches create a 76 bp overlap, which allows robust assembly of the two sequences, so that they encompass the entire barcoding region.

The PCR assays were performed in a total volume of $25 \mu \mathrm{l}$ using the FIREPol mastermix (Solis Biodyne) according to the manufacturer's instructions. The relative volumes of the PCR components were $17 \mu 1$ water, $1 \mu \mathrm{l}$ of each $10 \mathrm{mM}$ primer, $4.5 \mu \mathrm{l}$ of the master mix and $1.5 \mu \mathrm{l}$ of the genomic extract. The PCR protocols used 3 min initial denaturation, followed by 36 cycles of $30 \mathrm{~s}$ denaturation, $30 \mathrm{~s}$ annealing and $45 \mathrm{~s}$ extension, plus $3 \mathrm{~min}$ of final extension. Annealing temperatures were chosen as $53^{\circ} \mathrm{C}$ for the primer combination SK-FA336 + $\mathrm{HCO}$ and $50^{\circ} \mathrm{C}$ for the combination of the other two primers. PCR success was assessed on a 1.5\% Agarose gel using GelRed DNA staining and UV light to detect bands. PCR products were sent to Macrogen Europe for Sanger sequencing, and resulting AB1 files were analysed and assembled in MEGA X 10.0 (Kumar et al. 2018). The sequences newly generated in this study were uploaded on GenBank under accession numbers MT072689 to MT072694.

\section{Alignment and phylogenetic analysis}

The barcodes were translated into amino acids and aligned by hand in MEGAX, which was straightforward as no gaps were detected. We estimated uncorrected pairwise distances (from now on called 'p-distances') under pairwise deletion in cases of missing data. A phylogenetic tree was reconstructed using Bayesian inference in MrBayes 3.2.7 (Ronquist et al. 2012). The gene was partitioned into first plus second versus third codon positions and substitution model parameters unlinked across models. We used a mixturemodel for nucleotide substitution, invariant sites and a gamma distribution to model among-sites rate variation, and default settings for the other parameters. The analysis was run for 2 Mio generations, sampling every 1000 generations, after which the plotted log-likelihoods and all diagnostics indicated good convergence (ASDSF: 0.009; PRSF values all below 1.003; ESS all above 150). Alignment and resulting trees were uploaded on TreeBase. 


\section{Results}

Class Insecta Linnaeus, 1758

Order Hymenoptera Linnaeus, 1758

Superfamily Ichneumonoidea Latreille, 1802

Family Ichneumonidae Latreille, 1802

Subfamily Poemeniinae Narayanan \& Lal, 1953

Genus Neoxorides Clément, 1938

Neoxorides Clément, 1938: 517-519. Type species: Neoxorides nitens (Gravenhorst, 1829).

\section{Molecular Analyses}

The barcoding analysis showed small intraspecific and rather large interspecific distances (Table 1), thus confirming all species hypotheses of the taxa treated in this work (with the exception of $N$. varipes, for which we could not obtain a barcode). The largest intraspecific distance was found in N. collaris ( $0.8 \%$ p-distance), while the minimum interspecific distance was $4.6 \%$ (between $N$. striatus sp. nov. and N. montanus), leaving a barcoding gap of $3.6 \%$ (but this might decrease when more populations of each species are sampled).

The Bayesian phylogenetic analysis (Fig. 3) recovered all the species as monophyletic, although $N$. collaris was not strongly supported (likely because of one specimen only having half of the barcoding sequence). Neoxorides collaris shows a rather isolated position with respect to the morphologically similar $N$. striatus sp. nov. and N. montanus, which are recovered as sister groups.

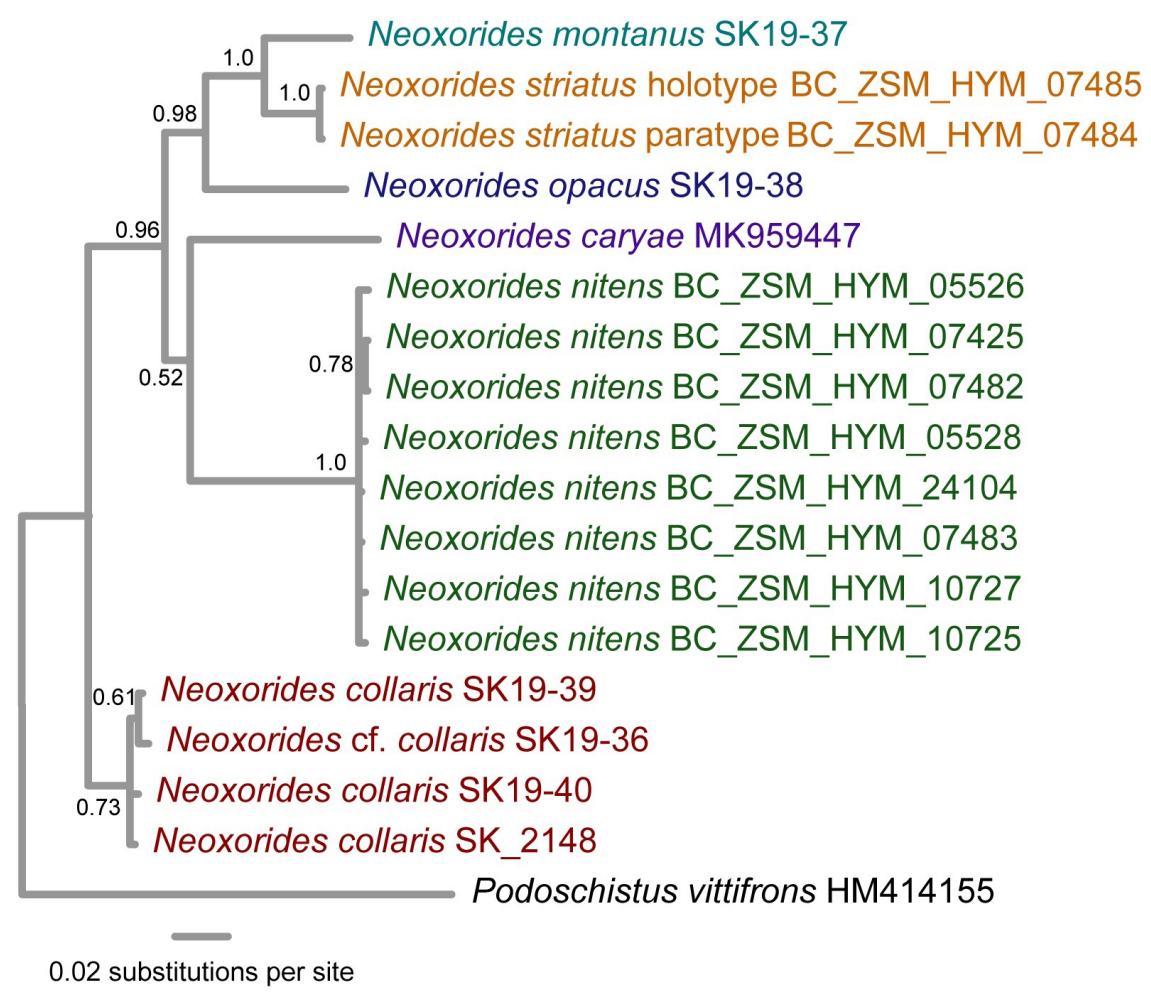

Fig. 3. Bayesian majority-rule consensus tree based on $\mathrm{CO} 1$ sequences, showing posterior probabilities of the recovered nodes within Neoxorides Clément, 1938. 
Table 1. Uncorrected pairwise distances of species of Neoxorides Clément, 1938.

\begin{tabular}{lccl}
\hline Species & Max. intraspecific & Min. interspecific & Closest species \\
\hline N. striatus sp. nov. & $0.00 \%$ & $4.63 \%$ & N. montanus \\
N. caryae & - & $8.28 \%$ & N. collaris \\
N. collaris & $0.8 \%$ & $7.01 \%$ & N. opacus \\
N. montanus & - & $4.63 \%$ & N. striatus \\
N. nitens & $0.46 \%$ & $7.34 \%$ & N. collaris \\
N. opacus & - & $7.01 \%$ & N. collaris \\
\hline
\end{tabular}

\section{Key to the Western Palaearctic species of Neoxorides}

The key to species is quite straightforward, but when separating $N$. collaris, N. montanus and N. striatus sp. nov., one should be aware that some of the characters partly overlap (see also Table 2). The determination should, therefore, be supported by a combination of characters. Generally, the yellow marking on the head and coxae are less distinct in small specimens; nevertheless, the colouration can be useful in species diagnostics. Previously used characters as the shape of the male genitalia and the shape of the flagellomeres (Oehlke 1966) have been found to be too variable to be of any significant use and are excluded from the key. The measurements of the metasomal segments represent typical specimens, and the overlap makes it necessary to use this character in combination with the other characters given in the key. While the white spots along the inner orbits above the antennal scobes are surprisingly consistent in shape, the white line below the scrobes is very variable within species and can be distinct, diffuse or missing.

The subfamily Poemeniinae can be keyed out using Broad et al. (2018). The genus Neoxorides is then separated from other genera of the subfamily by the scale-like structure of the temples in combination with the entirely black scutellum and the indistinct punctures on the tergites.

1. Scutellum and postscutellum with yellow apices; second and third tergite with distinct punctures ..

Podoschistus scutellaris (Desvignes, 1856)

- Scutellum and postscutellum black; second and third tergite with indistinct punctures ................. 2

2. Anterior part of pronotum centrally raised as a collar (Fig. 5C); mesopleuron and mesosternum polished with scattered punctures (Fig. 4C); male with face black centrally. Primarily connected to hosts on oak

Neoxorides nitens (Gravenhorst, 1829)

- Anterior part of pronotum unmodified; mesopleuron and mesosternum with distinct microsculpture (Fig. 4A-B); male with face white

3. Propodeum dorsally with rugose sculpture (Fig. 6B); mandibular teeth wide with almost parallel sides (Fig. 7C); pronotum laterally without white line. Possibly connected to hosts on aspen Neoxorides opacus (Kokujev, 1903) stat. rev.

- Propodeum dorsally shagreened or with faint striate microsculpture (Fig. 6A); mandibular teeth (when unworn) apically narrowed (Fig. 7D); pronotum usually with white line laterally (sometimes absent in very small specimens). Primarily connected to hosts on conifers

4. Hind coxae brown or black; sides of pronotum with weak, reticulate microsculpture (Fig. 5B); white spots along inner orbits above antennal sockets very short (Fig. 5A)

Neoxorides varipes (Holmgren, 1860)

- Hind coxae orange; sides of pronotum in lower part polished, without microsculpture (Fig. 5D, G); white spots along inner orbits above antennal sockets longer (Fig. 7B) 
5. Frons weakly transversely striate over most of its surface (Fig. 1B); sides of pronotum in female and male centrally with distinct striae that extend slightly backwards to upper part (as in Fig. 5G); metapleural furrow with distinct transverse carinae (Fig. 1C); pale marks along inner orbits above antennal scrobes in female short, about 2.0-2.5 times as long as wide (Fig. 9B); first tergite in female about 2.0-2.3 times as long as wide (Fig. 9E); mid coxae in female orange; white stripe on pronotum in male and female slender, at most one third as wide as width of fore femur (as in Figs 1A, 5D); face in male narrow (Fig. 9H) Neoxorides striatus Johansson sp. nov.

- Frons evenly shagreened without obvious striae (Fig. 7B); metaplural furrow with transverse carinae less distinct (Figs 4B, 6E); if sides of pronotum have striae centrally that extend backwards to the upper part (Fig. 5G), then mid coxae have extensive yellowish markings and white line of pronotum is as wide as the width of the fore femur (Fig. 5G); face in male usually wider (Fig. 9G) 6

6. Sides of pronotum in female and often in male centrally with transverse striae that extend backwards to upper part (Fig. 5G); white stripe on pronotum in male and female wider, about as wide as the width of fore femur (Fig. 5G); mid coxae in female with extensive yellow or whitish marks on outer side (absent in small females); pale marks along inner orbits above antennal scrobes in female usually stouter, about 2.0 times as long as wide, slightly widened in upper part, rounded (Fig. 9C); first tergite in female usually about 2.4-2.5 times as long as wide (Fig. 9F), sometimes shorter, in male usually about 3.5 times as long as wide; ovipositor about as long as metasoma, slender and weak, usually curved downwards, sinuate or partly curled up in dried up specimens, rarely evenly upcurved

Neoxorides montanus (Oehlke, 1966)

- Sides of pronotum centrally usually without microsculpture (Fig. 5D), if weak striae are present, they do not extend upwards/backwards; white stripe on pronotum in male and female usually slender (wider in large males), at most 0.5 times as wide as width of the fore femur (Fig. 5D); mid coxae orange in female, rarely with small whitish mark apically in large specimens; pale marks along inner orbit above antennal scrobes in female narrower, about 3.0 times as long as wide, parallel or converging in upper part (Fig. 9A); first tergite in female usually about 1.7-1.9 times as long as wide (Fig. 9D), in male usually about 2.0-2.5 times as long as wide; ovipositor about as long as metasoma minus the first tergite, stouter, curved upwards Neoxorides collaris (Gravenhorst, 1829)

\section{Systematics}

Neoxorides collaris (Gravenhorst, 1829)

Figs 4B, 5D, 6A, C, E, 7B, D, 9A, D

Xorides collaris Gravenhorst, 1829: 848-849.

Xorides collaris var. harpii Fahringer, 1935 in Schimitschek 1935: 139.

Neoxorides collaris - Clément 1938: 517-518. - Oehlke 1966: 890-891, fig. 4. - Kasparyan 1981: 94. - Kanders 2009: 9. - Varga 2015: 3-4, figs 1, 4.

Xorides collaris - Ratzeburg 1848: 105. — Holmgren 1860: 65. - Dalla Torre 1901-1902: 381-382. — Schmiedeknecht 1907: 17; 1908: 1368. — Hellén 1915: 20. — Haupt 1917: 82.

\section{Diagnosis}

This species has proven notoriously difficult to identify with previous keys, and we here give a detailed diagnosis to clarify how it is distinct from other species of the genus. Neoxorides collaris is a species that is quite variable in size with a fore wing length of $8-12 \mathrm{~mm}$. The metasoma in the female is stout with the first tergite about 1.7-1.9 times as long as wide. The ovipositor is relatively short and stout, curved upwards and usually about as long as the metasoma minus the first tergite. The female has the lateral part of pronotum with irregularly punctate rugose structure only in the upper half, while the 
lower half is polished without microsculpture (Fig. 5D). If the central part occasionally has weak striae, they never extend into the upper part backwards/upwards as in N. montanus and N. striatus sp. nov. (Fig. 5G). The mesopleural furrow usually lacks any distinct transverse carinae and if carinae are present, they are usually less distinct and denser (Figs 4B, 6E). The colouration of the fore coxae ranges from orange, sometimes with the basal half infuscate, to having the apical part more or less extensively yellow. The mid coxae are usually entirely orange in the females, thereby differing from the largely yellow apices of the mid-coxae in the female of $N$. montanus. The female is distinguished from $N$. nitens and $N$. opacus by the combination of the unmodified pronotal collar, the weakly aciculate dorsal portion of the propodeum (Fig. 6A) and the tergites, as well as the aciculate/shagreened mesopleuron/mesosternum with weak, but clearly discernible punctures (Fig. 4B). Neoxorides collaris is distinguished from $N$. varipes by the orange or partly orange hind coxae and the absence of reticulate microsculpture on the sides of the pronotum. The female is distinguished from $N$. montanus by the shorter and upcurved ovipositor, the usually stouter first tergite, the structure and the narrower white line on the sides of pronotum, and in most cases by the shape of the pale markings along the inner orbits above the antennal scrobes, which are narrower and have more parallel inner sides (Fig. 9A). The most useful character when separating the males of $N$. collaris and $N$. montanus seems to be the relative length of the metasoma, usually expressed in the shape of the first tergite. In N. montanus, it is usually longer, about 3.0-3.5 times as long as wide, while it is about 2.5 times as long as wide in N. collaris. In small males of $N$. collaris, the hind coxa in the male is apically/dorsally more or less infuscate and the hind femur is at least dorsally infuscate. The weak infuscation of the hind femur dorsally is evident also in Scandinavian females. Frequently, the entire hind femur in the male is brownish with a reddish ring basally. The hind trochanter and trochantelli in the male are usually dark brown dorsally and white ventrally. In Nordic specimens, the mid coxae are largely yellow on the outer side in N. montanus, while they are entirely orange, rarely with a small yellowish spot, in $N$. collaris. From $N$. striatus sp. nov., $N$. collaris is distinguished by the evenly shagreened frons, the structure of the pronotum, the absence of transverse carinae in the mesopleural furrow (Fig. 6E), the wider face in the male (as in Fig. 9G) and the stouter metasoma (Fig. 9D).

\section{Material examined}

Lectotype

POLAND・ ^־; NMWU.

Other material

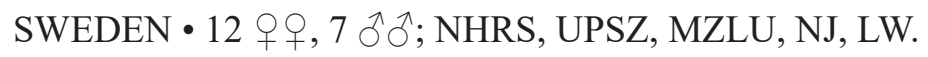

GERMANY・ 1 §; MR.

FINLAND 3 우, 1 §ิ; MZH.

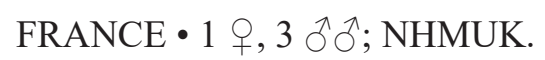

UKRAINE $\bullet 1$ \%; OV.

\section{Ecology}

Neoxorides collaris is connected to cerambycids feeding on conifers. Most specimens have been collected in coniferous forests dominated by scots pine Pinus sylvestris L. or on scots pine timber (first author pers. obs.). 


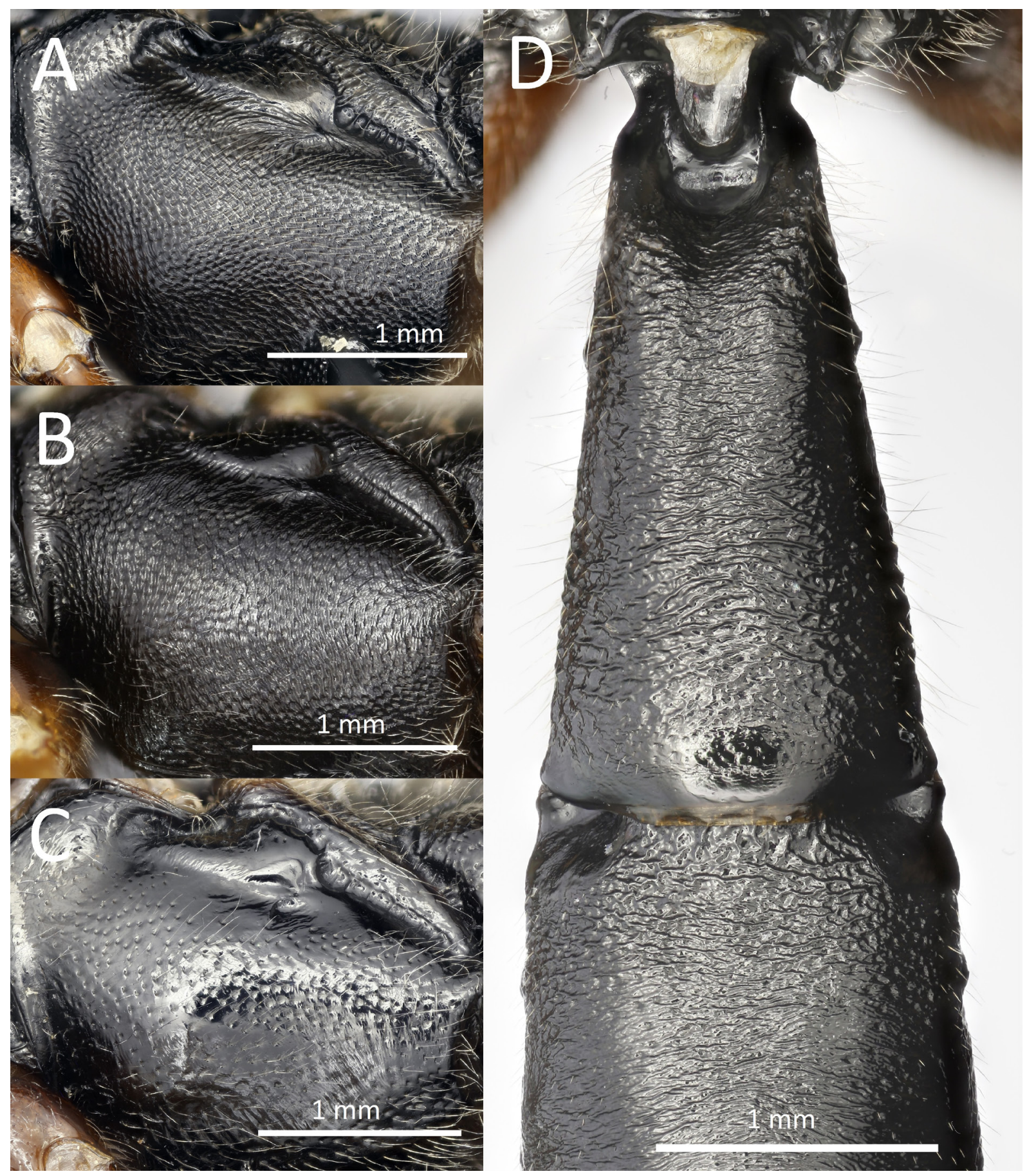

Fig. 4. A. Neoxorides opacus (Kokujev, 1903) stat. rev., $q$ (NJ), mesopleuron, lateral view. B. $N$. collaris (Gravenhorst, 1829), ㅇ (NJ), mesopleuron, lateral view. C. N. nitens (Gravenhorst, 1829), ㅇ (NJ), mesopleuron, lateral view. D. $N$. opacus, $q$ (NJ), basal portion of metasoma, dorsal view. Photos: Alexander Berg. 
Table 2. Distinguishing characters for Neoxorides collaris (Gravenhorst, 1829), N. montanus (Oehlke, 1966) and N. striatus Johansson sp. nov.

\begin{tabular}{|c|c|c|c|}
\hline Character/Species & N. collaris & N. montanus & $N$. striatus sp. nov. \\
\hline $\begin{array}{l}\text { Structure of pronotum } \\
\text { laterally, central and } \\
\text { upper part }\end{array}$ & $\begin{array}{l}\text { centrally polished, in } \\
\text { upper part punctate rugose } \\
\text { (Fig. 5D). }\end{array}$ & striate (Fig. 5G). & striate (as in Fig. 5G). \\
\hline Mesopleural furrow & $\begin{array}{l}\text { without distinct transverse } \\
\text { carinae (Fig. } 6 \mathrm{E} \text { ). }\end{array}$ & $\begin{array}{l}\text { without distinct transverse } \\
\text { carinae (as in Fig. 6E). }\end{array}$ & $\begin{array}{l}\text { with distinct transverse } \\
\text { striae (Fig. 1C). }\end{array}$ \\
\hline $\begin{array}{l}\text { Colour of mid coxae in } \\
\text { female }\end{array}$ & $\begin{array}{l}\text { orange, at most with small } \\
\text { yellow spot on the outer } \\
\text { side }\end{array}$ & $\begin{array}{l}\text { with large yellow spot on } \\
\text { the outer side }\end{array}$ & $\begin{array}{l}\text { orange, at most with small } \\
\text { yellow spot on the outer } \\
\text { side }\end{array}$ \\
\hline $\begin{array}{l}\text { White spots along inner } \\
\text { orbits above antennal } \\
\text { scrobes in female }\end{array}$ & $\begin{array}{l}\text { narrow, frequently } \\
\text { converging upwards } \\
\text { (Fig. 9A). }\end{array}$ & $\begin{array}{l}\text { wide, usually diverging } \\
\text { upwards (Fig. 9C). }\end{array}$ & $\begin{array}{l}\text { medium wide with almost } \\
\text { parallel sides (Fig. 9B). }\end{array}$ \\
\hline $\begin{array}{l}\text { White line on pronotum } \\
\text { laterally in female }\end{array}$ & narrow (Fig. 5D). & wide (Fig. 5G). & narrow (as in Figs 5B, D). \\
\hline Ovipositor in female & shorter, stouter & longer, weaker & longer, weaker \\
\hline Structure of frons & $\begin{array}{l}\text { evenly shagreened } \\
\text { (Fig. 7B). }\end{array}$ & $\begin{array}{l}\text { evenly shagreened (as in } \\
\text { Fig. 7B). }\end{array}$ & $\begin{array}{l}\text { weakly transversely } \\
\text { striate (Fig. 1B). }\end{array}$ \\
\hline First tergite in female & $\begin{array}{l}1.7-1.9 \text { times as long as } \\
\text { wide (Fig. 9D). }\end{array}$ & $\begin{array}{l}2.4-2.5 \text { times as long as } \\
\text { wide (Fig. 9F). }\end{array}$ & $\begin{array}{l}2.0-2.3 \text { times as long as } \\
\text { wide (Fig. } 9 \mathrm{E} \text { ). }\end{array}$ \\
\hline First tergite in male & $\begin{array}{l}\text { about } 2.5 \text { times as long as } \\
\text { wide }\end{array}$ & $\begin{array}{l}\text { about } 3.5 \text { times as long as } \\
\text { wide }\end{array}$ & $\begin{array}{l}\text { about } 3.0 \text { times as long as } \\
\text { wide }\end{array}$ \\
\hline Face in male & wide (as in Fig. 9G). & wide (Fig. 9G). & narrow (Fig. 9H). \\
\hline
\end{tabular}

\section{Distribution and status in Sweden}

Neoxorides collaris occurs over most of the country, especially in light forests with dead wood or in burned forests. Ha, Hs, Sm, Sö, Up, Vb, Ög.

\section{Remarks}

Some of the distinguishing characters previously used to separate this species from N. montanus, such as the shape of the male genitalia and the shape of the basal flagellomeres in the female, appear partly unreliable. However, the species is usually easily distinguished by the characters listed in the key and the diagnosis. The type of N. collaris var. harpii (Fahringer, 1935 in Schimitschek 1935) is lost (Horstmann 1988). The original description (p. 139) refers to a rearing from Rhagium inquisitor (Linnaeus, 1758) and mentions characters that could be attributed to several species of Neoxorides. With the current level of knowledge, this variety cannot be properly interpreted and we chose the more conservative point of view and follow the synonymy proposed by the original author.

\section{DNA barcode}

The barcodes of Neoxorides collaris are separated from their closest barcodes (in N. opacus) by at least $7.0 \%$ p-distance. The sequences are available on GenBank under accession numbers: MT072689 (SK19_39), MT072690 (SK19_40), MT072694 (SK_2148), MT072693 (SK19_36). 


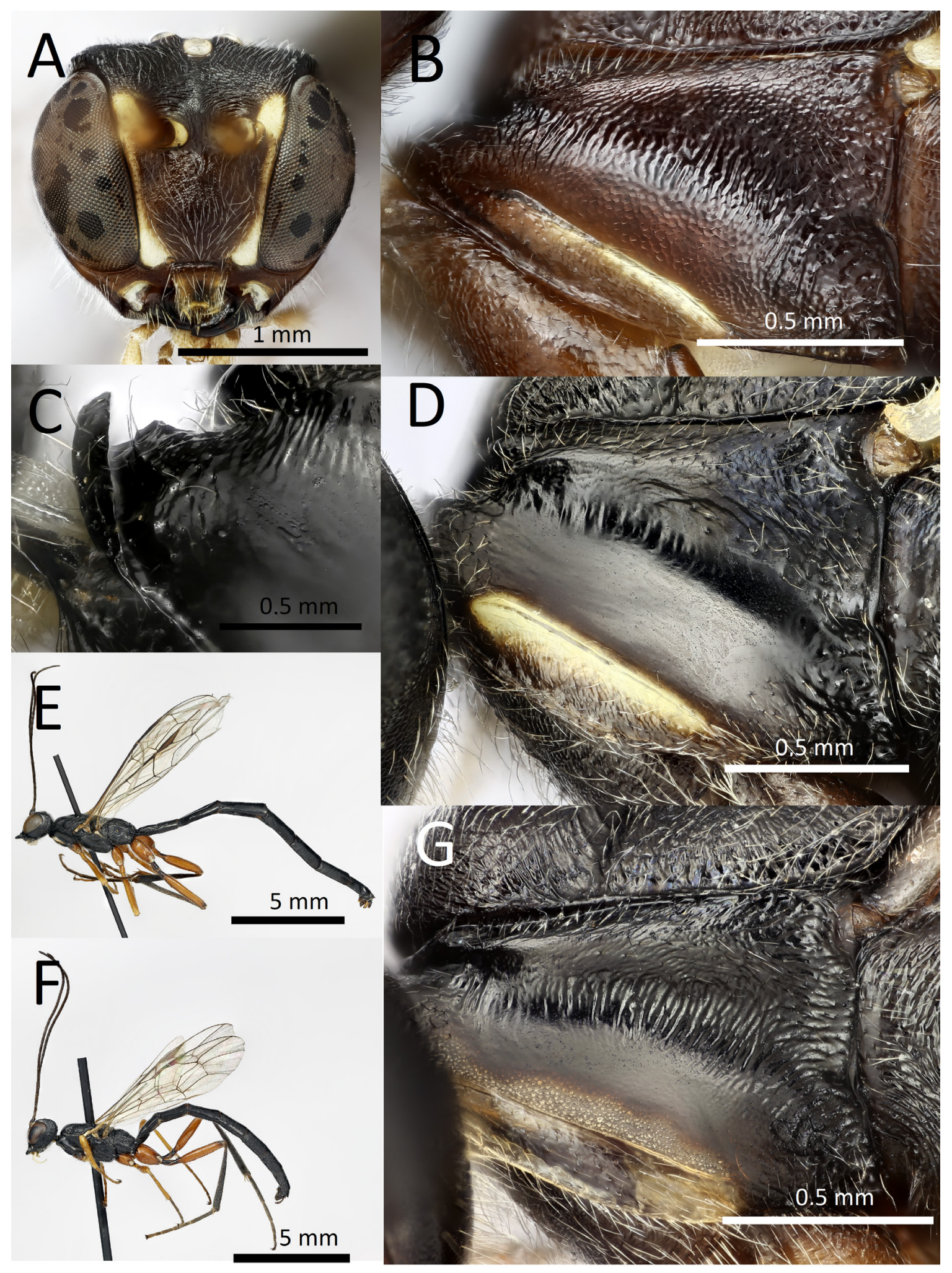

Fig. 5. A. Neoxorides varipes (Holmgren, 1860),, , MZH, head, anterior view. B. N. varipes, $q$ (MZH), pronotum, lateral view. C. $N$. nitens (Gravenhorst, 1829), \& (NJ), central anterior part of pronotum, lateral view. D. $N$. collaris (Gravenhorst, 1829), $\stackrel{+}{ }(\mathrm{NJ})$, pronotum, lateral view. E. $N$. nitens, $\widehat{\partial}(\mathrm{NJ})$, form with long metasoma, lateral view. F. N. nitens, ô (NJ), form with short metasoma, lateral view. G. N. montanus (Oehlke, 1966), $q$ (NJ), pronotum, lateral view. Photos: Alexander Berg. 
Neoxorides montanus Oehlke, 1966

Figs $5 \mathrm{G}, 9 \mathrm{C}, \mathrm{F}-\mathrm{G}$

Neoxorides montanus Oehlke, 1966: 889-890, fig. 3.

Neoxorides montanus - Kasparyan 1981: 94.

\section{Diagnosis}

Neoxorides montanus is a species that is quite variable in size, with a fore wing length of 9-14 mm, on average slightly larger than $N$. collaris. The metasoma in the female is more elongate with the first tergite about 2.5 times as long as wide (Fig. 9F). The ovipositor in the female is usually as long as the metasoma and quite narrow and weak. In mounted specimens it is usually curved downwards, sinuate or curled up due to this weakness. The mid coxae in both sexes are largely yellow apically. The whitish spots along the inner orbits above the antennal scrobes are large and rounded in females (Fig. 9C) and the white lines on the sides of the pronotum are wide, usually as wide as the width of the fore femur (Fig. 5G). Neoxorides montanus is most similar to $N$. collaris and $N$. striatus sp. nov., but is distinguished by the characters given in the key to species and Table 2 .

\section{Material examined}

Holotype

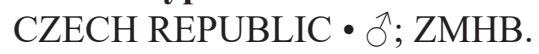

Paratypes

GERMANY • 3 우; ZMHB $・ 1$ 令; NHRS.

Other material

SWEDEN・6 우, 2 ふ઼ึ; MZLU, NJ, LW.

FINLAND・4 9 ㅇ, 11 ふふ; MZH.

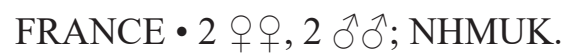

GERMANY • 3 +,$+ 3 \widehat{\jmath}$ ○; MR, NHMUK, MZH.

UKRAINE $\bullet 1$ \%; OV.

\section{Ecology}

Neoxorides montanus is connected to cerambycids feeding on conifers. It has been reared from larch along with the cerambycid Tetropium gabrieli Weise, 1905 (first author pers. obs.). Most records are from spruce Picea abies (L.) H.Karst. dominated forests, which possibly might indicate that the main hosts are Tetropium fuscum (Fabricius, 1787) and/or T. castaneum (Fabricius, 1787) (Kenis \& Hilszczański 2004).

\section{Distribution and status in Sweden}

Most records are from the southern and central parts of the country, but it can probably be expected to occur also up in the north. Go, Hs, Sm.

\section{Remarks}

Among the distinguishing characters used to define and describe $N$. montanus, the relative length of the basal flagellomeres in the female and the shape of the male genitalia seem to be of limited use. 


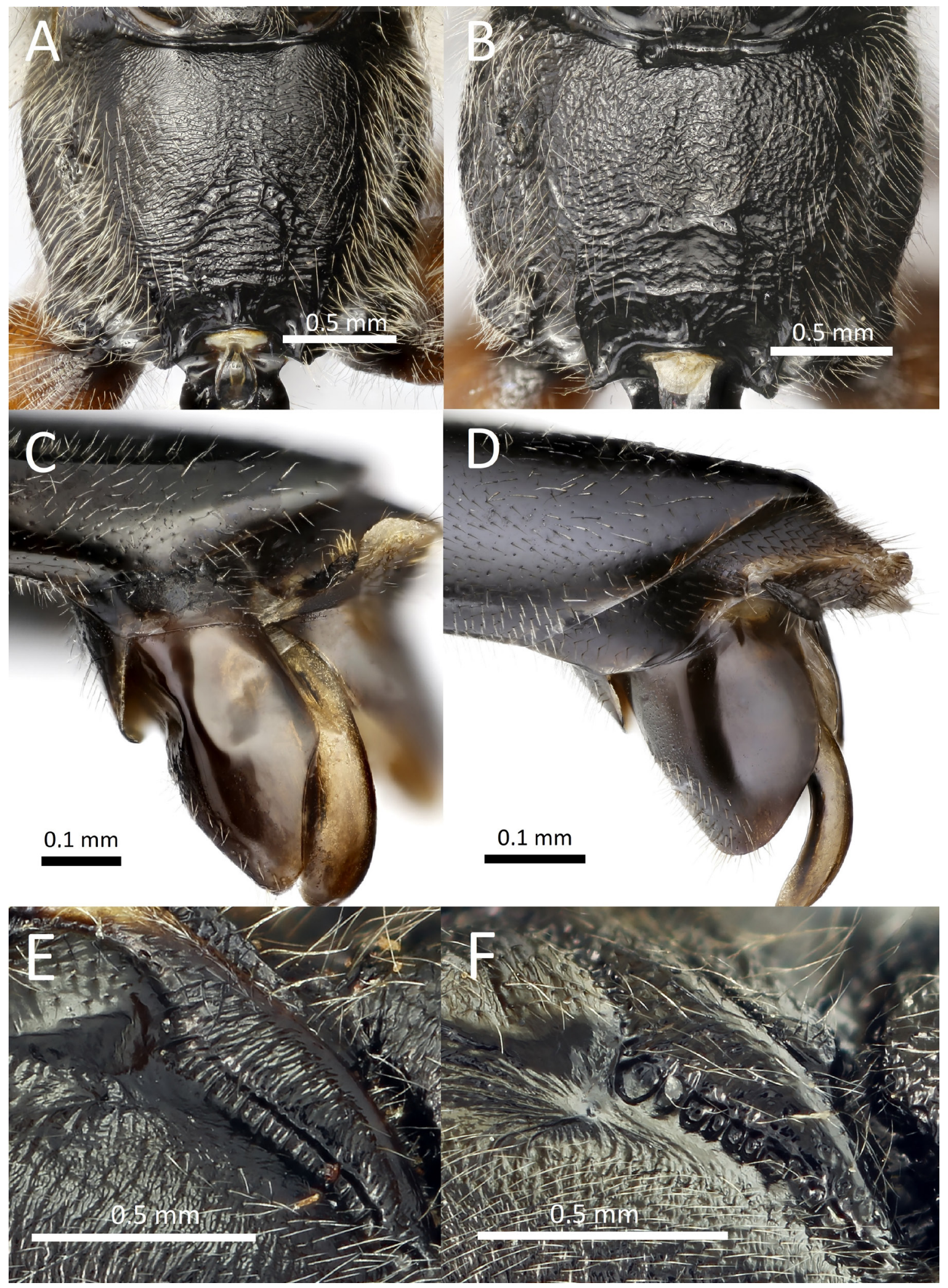

Fig. 6. A. Neoxorides collaris (Gravenhorst, 1829), $q$ (NJ), propodeum, dorsal view. B. N. opacus (Kokujev, 1903) stat. rev., + (NJ), propodeum, dorsal view. C. N. collaris, § (NJ), parameres, lateral view. D. N. opacus, $\hat{\jmath}(\mathrm{NJ})$, parameres, lateral view. E. N. collaris, $q(\mathrm{NJ})$, mesopleural furrow, lateral view. F. N. opacus, $q$ (NJ), mesopleural furrow, lateral view. Photos: Alexander Berg. 
According to the original description, the female of $N$. collaris is said to have the second flagellomere at most 5.2 times as long as wide while it is at least 5.5 times as long as wide in $N$. montanus. Given the natural variation in the shape of the flagellomeres (which are often oval in cross section) often amplified during preparation and preservation, this small difference is of no practical significance. The male of $N$. montanus usually has the parameres (and the hind margins of the tergites) more weakly sclerotized than in $N$. collaris and $N$. striatus sp. nov., which often makes them heavily deformed during storage or preparation. Newly hatched specimens or specimens of other species stored in ethanol also often display this deformation, making it hard to draw any definitive conclusions from the shape of the genitalia. We, therefore, recommend that the shape of the parameres is only used in combination with other characters. Apart from the shape of the male genitalia and the shape of the flagellomeres, the only diagnostic character used in the original description is the relative length of the metasomal segments. This seems to be a quite consistent character, but one should be aware that overlap frequently occurs with $N$. striatus sp. nov. and even $N$. collaris. During this study, it was also noted that the males of $N$. nitens and also $N$. striatus sp. nov. seem to be rather variable regarding the length of the metasomal segments (Fig. 5E-F). Both the holotype of N. montanus (Oehlke 1966) and the lectotype of $N$. collaris (Jałoszyński \& Wanat 2014) are males, and this variation regarding the relative length of the metasoma could present a problem regarding the identity of the type specimens. However, all males of $N$. collaris studied by the first author have stouter metasoma, and all males of N. montanus have the more slender form, which indicates that these aberrant forms are rare. The additional colour characters of the lectotype of $N$. collaris and the holotype of $N$. montanus, respectively, i.e., the shape of the white spots along the inner orbits above the antennal scobes, also supports the validity of each species.

\section{DNA barcode}

The barcode of this species is separated from its closest barcode (in N. striatus sp. nov.) by $4.6 \%$ p-distance. The sequence is available on GenBank under accession number: MT072691 (SK19_37).

Neoxorides nitens (Gravenhorst, 1829)

Figs 4C, 5C, E-F

Xorides nitens Gravenhorst, 1829: 847-848.

Neoxorides nitens var. albicollis Clément, 1938: 518.

Neoxorides nitens var. nigrifacis Clément, 1938: 518.

Neoxorides nitens - Clément 1938: 518. — Oehlke 1966: 888-889. — Kasparyan 1981: 94. — Kolarov 1997: 2014. - Varga 2015: 4, fig. 3.

Xorides nitens - Holmgren 1860: 65. — Dalla Torre 1901-1902: 382. — Schmiedeknecht 1908: 1369.

\section{Diagnosis}

Fore wing length 7-13 mm. Neoxorides nitens is distinguished from other species of the genus by the more or less polished and scarcely punctate mesosternum and mesopleuron (Fig. 4C). The anterior part of the pronotum is reflexed as a lamella (Fig. 5C), a feature which is sometimes less distinct in small males. The male, however, is easily separated based on the black central area of the face, a feature not present in any other species of the genus in the Western Palaearctic. The colouration of both female and male is usually quite dark with the tegulae, sides of the pronotum and palpi black or dark brown, and the coxae orange, devoid of any whitish or yellow spots. However, quite often, the lower part of the pronotum has a white line laterally (var. albicollis (Clément 1938)). Based on the colouration alone, the species is most likely to be confused with N. opacus, but the male of that species has the face entirely white and both sexes have the mesopleuron and mesosternum more densely punctate-rugose on a shagreened background. 


\section{Material examined}

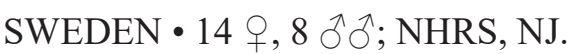

GERMANY 2 2 +q, 1 ○ं; MR.

\section{Ecology}

In Sweden, $N$. nitens is probably connected to cerambycids feeding on oak Quercus L. Kasparyan (1981) lists a variety of hosts and though some of them, such as Plagionotus detritus (Linnaeus, 1758) and Pyrrhidium sanguineum (Linnaeus, 1758), feed on oak and might have been reared from the same substrate, the only authenticated rearing record seems to be from the cerambycid Phymatodes testaceus (Linnaeus, 1758) and the buprestid Ovalisia mirifica (Mulsant, 1855) (Broad et al. 2018). The latter is monophagous on elm Ulmus L. sp. and does not occur in Sweden.

\section{Distribution and status in Sweden}

Locally abundant in Southern Sweden in areas with oak. Bl, Ha, Sk, Sm, Ög, Öl.

\section{Remarks}

The male is very variable regarding the length of the metasoma (Fig. 5E-F).

\section{DNA barcode}

The barcodes of this species are separated from their closest barcode (in N. collaris) by 7.3\% p-distance. The sequences are stored on BOLD under accession numbers: FBICA016-10 (BC ZSM HYM 05526), FBICA110-11 (BC ZSM HYM 07425), FBICA018-10 (BC ZSM HYM 05528), BCHYM10139-15 (BC ZSM HYM 24104), FBICA168-11 (BC ZSM HYM 07483), FBICA167-11 (BC ZSM HYM 07482), FBICA562-11 (BC ZSM HYM 10727), FBICA560-11 (BC ZSM HYM 10725).

Neoxorides opacus (Kokujev, 1903) stat. rev.

Figs 4A, D, 6B, D, F, 7A, C, 8A-C

Xorides opacus Kokujev, 1903: 287.

Xorides kissi Ulbricht, 1911: 151.

Neoxorides opacus - Clément 1938: 518.

Neoxorides nitens (partim) - Oehlke 1966: 888-889.

\section{Diagnosis}

Neoxorides opacus (Fig. 8A-B) is distinguished from other species of Neoxorides by the combination of the densely punctate and partly rugulose mesosternum, mesopleuron and metapleuron (Fig. 4A), the roughly sculptured propodeum (Fig. 6B) and face, the apically wider mandibles (Fig. 7C), the dark pronotum and palpi, and the rounded shape of the male parameres (Fig. 6D). It is, despite the previously suspected synonymy with $N$. nitens, most likely to be confused with dark-coloured specimens of $N$. striatus sp. nov., but has the mandibles stouter and the mesopleuron and mesosternum more densely and distinctly punctate. The structure of the propodeum basally (Fig. 6B) and the basal tergites (Fig. 4D) are largely rugulose in $N$. opacus while they are more or less aciculate in $N$. collaris (Fig. 6A), $N$. montanus and $N$. striatus sp. nov. Furthermore, the white stripe along the inner orbit of both sexes is usually continuous in $N$. collaris (Fig. 7B), while it is interrupted at the level of the antennal scrobes in all known specimens of $N$. opacus (Fig. 7A). 


\section{Material examined}

Neotype (here designated)

RUSSIA • +; "Région du Baikal, Environ d'Irkoutsk" [Baikal area, surroundings of Irkutsk]; "174-96"; J. Chaffanjon leg.; MNHN.

\section{Other material}

RUSSIA $・ 1$; MR.

ROMANIA • 1 +, lectotype of Neoxorides kissi (Ulbricht, 1911); "Ferenczfalva" [Văliug]; coll. Z. Kiss E.; HNHM-HYM 104461 • 1 J, paralectotype of Neoxorides kissi (Ulbricht, 1911); "Ferenczfalva" [Văliug]; coll. Z. Kiss E.; HNHM-HYM 104465 (coll. Z. Kiss E.).

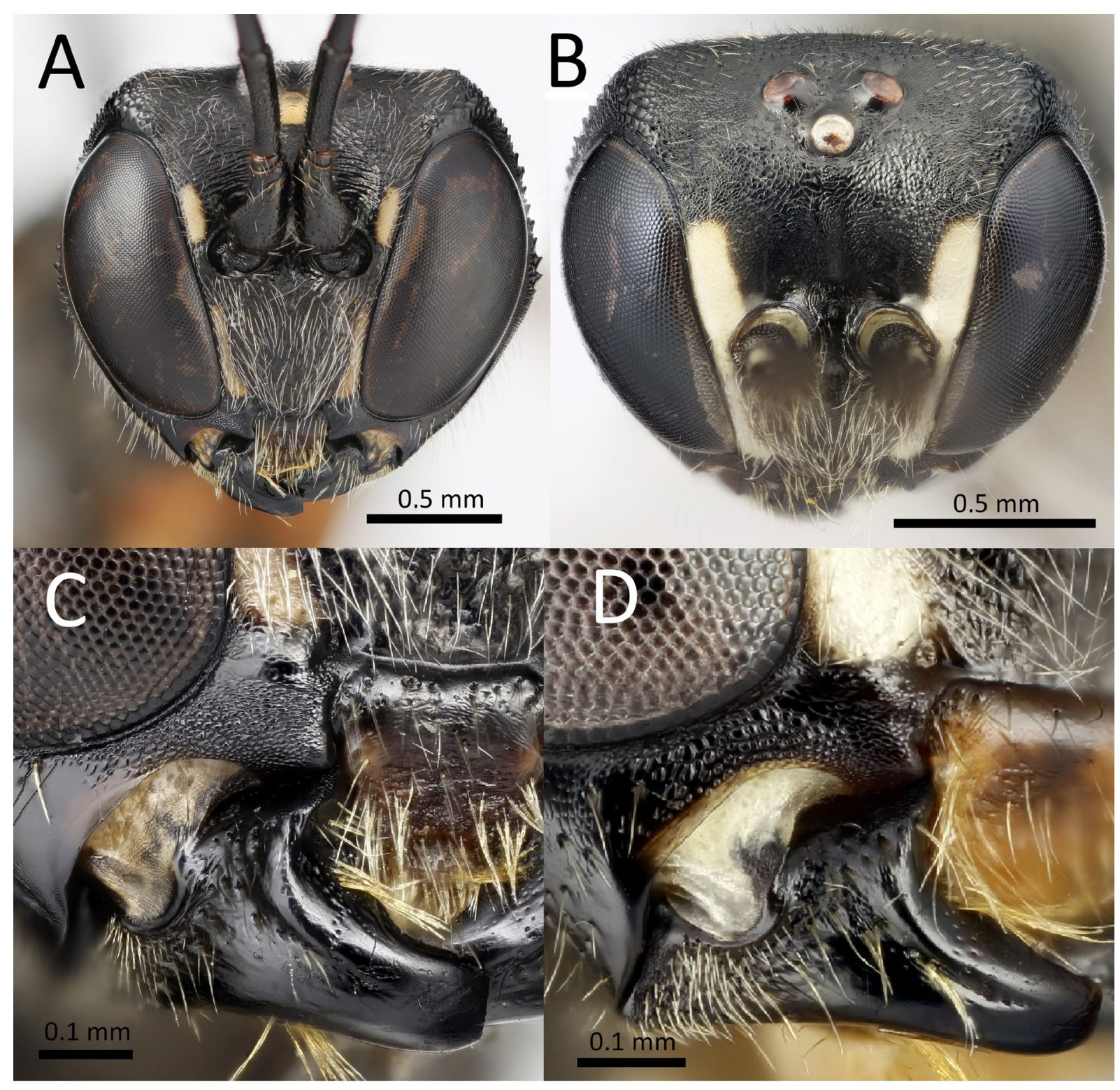

Fig. 7. A. Neoxorides opacus (Kokujev, 1903) stat. rev., $q(\mathrm{NJ})$, head, anterior view. B. N. collaris (Gravenhorst, 1829), $q(\mathrm{NJ})$, head, anterodorsal view. C. N. opacus, $q$ (NJ), mandible, lateral view. D. . collaris, $\uparrow(\mathrm{NJ})$, mandible, lateral view. Photos: Alexander Berg. 


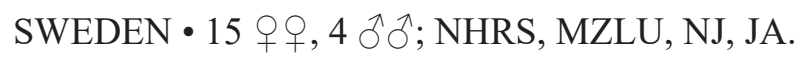

SOUTHERN EUROPE 1 1 ; coll. Förster; ZMHB.

\section{Redescription}

Fore wing length $8.5-13.5 \mathrm{~mm}$. Antenna in both sexes with 29-32 flagellomeres. First to fourth flagellomere about 5.0 times as long as wide. Central flagellomeres stout, about 1.5-1.7 times as long as wide. Subapical flagellomeres approximately $0.8-1.0$ times as long as wide. Temple slightly widened behind eyes in dorsal view, with coarse scale-like structure following outer and upper margin of compound eye. Frons above antennal sockets weakly transversely striate (Fig. 7A). Head dorsally, behind compound eyes, with rather distinct punctures that are denser and more distinct than in $N$. collaris. Inner orbits strongly converging (Fig. 7A). Face below antennal sockets rugulose. Mandible chisel-shaped, with more parallel sides and wider edge (Fig. 7C) than in N. collaris (Fig. 7D) and N. nitens. Malar space short, about 0.1 times as wide as mandibular base (Fig. 7A, C). Wing membrane clear (Fig. 8B). Pronotum centrally unmodified, not raised as in $N$. nitens. Mesosternum and mesopleuron densely punctate, partly rugulose (Fig. 4A) with punctures denser and more distinct than in N. collaris (Fig. 4B) and denser than in N. nitens (Fig. 4C). Mesopleural furrow with transverse carinae (Fig. 6F). Mesoscutum densely punctate on sides, punctures often merging. Mesoscutum centrally transversely strigose. Notauli deeply impressed, dividing mesoscutum into three lobes. Scutellum with deep punctures on a mostly polished surface. Propodeum basally rugulose (Fig. 6B), while it is smoother and slightly aciculate in N. collaris (Fig. 6A), N. montanus, N. striatus sp. nov. and N. nitens, and centrally in front of area petiolaris with irregular transverse ridges. First tergite in female 2-2.5 times as long as wide (Fig. 4D). Sclerotised section of the first sternite with a raised keel-like projection centrally. First tergite with coarse sculpture consisting of transverse striation centrally and irregular punctures on the sides (Fig. 4D), the striae larger than in other species of the genus. Second tergite in female distinctly punctate-rugulose, basally striate, tergites 3-7 weakly transversely aciculate. Second tergite in male distinctly punctate. Tergite 3-7 in male polished with very weak rather scarce punctures that are more distinct basally on tergite 3 . Male parameres apically rounded, about as long as wide (Fig. 6D), thereby differing from more elongate and apically narrowed parameres of $N$. collaris (Fig. 6C) and $N$. nitens. Note that the usually more weakly sclerotized parameres in $N$. collaris, $N$. montanus, $N$. striatus sp. nov. and $N$. nitens are more often deformed due to being dried up. Ovipositor sheath pilose, about as long as the fore wing (Fig. 8B).

\section{Colouration}

Body black. Inner orbit in female with a white stripe that is interrupted level with antennal sockets (Fig. 7A). Face entirely, a line along the inner orbits above the antennal sockets, isolated from the white colouration of the face, and the ventral side of scapus white in male. Tegulae and palpi black or brownish. Tegulae in the neotype of $N$. opacus (Figs 8A-C) and lectotype of $N$. kissi more whitish. Palpi occasionally paler light brown. Antennae black. Wing veins fuscous and pterostigma testaceous, fuscous along anterior margin. All coxae orange in male and female without any trace of yellow or white markings. Coxae sometimes with infuscate spot basally. Legs orange, hind tibia and hind and mid tarsi black, hind tibia sometimes brownish in basal 0.1. Joint between hind trochantellus and femur slightly infuscate. Fore and mid femur and tibia sometimes yellow anteriorly.

\section{Ecology}

All specimens for which the dates of collection are known were collected between late April and late August, indicating a prolonged period of activity or two overlapping generations. The dates of the collected specimens indicate that the main period of activity is May in Sweden. Two series, each consisting of five specimens, were collected by Malaise Traps placed near fresh logs and high stumps of aspen Populus tremula L. An identical trap, next to a pile of logs of Betula L. spp., Alnus glutinosa (L.) 
Gaertn. and Salix caprea L. between the two Populus L. traps caught no individuals. The two specimens collected with window traps in Grytsbergen and Tasvik in Östergötland have the sclerotization of the cuticula and wing veins weakly developed, indicating that they were newly hatched when they were collected. Both of these localities were involved in a project to investigate the species richness of saproxylic Coleoptera on aspen, and the traps were mounted on dead or dying trunks of aspen (Håkan Andersson, Linköping, pers. com.). Five of the remaining known Swedish specimens were collected in traps adjacent to or attached to dead trunks of aspen. These records could indicate that the host or hosts are to be found among cerambycids feeding on aspen. Xylotrechus rusticus (Linnaeus, 1758) and Saperda perforata (Pallas, 1773) are both common species at the Björneberg locality, where seven females and four males were collected. Both of these species have wide Palaearctic distributions.

\section{Distribution and status in Sweden}

Widespread in the eastern parts of Southern and Central Sweden in areas with aspen. Gs, Sö, Ög, Öl.

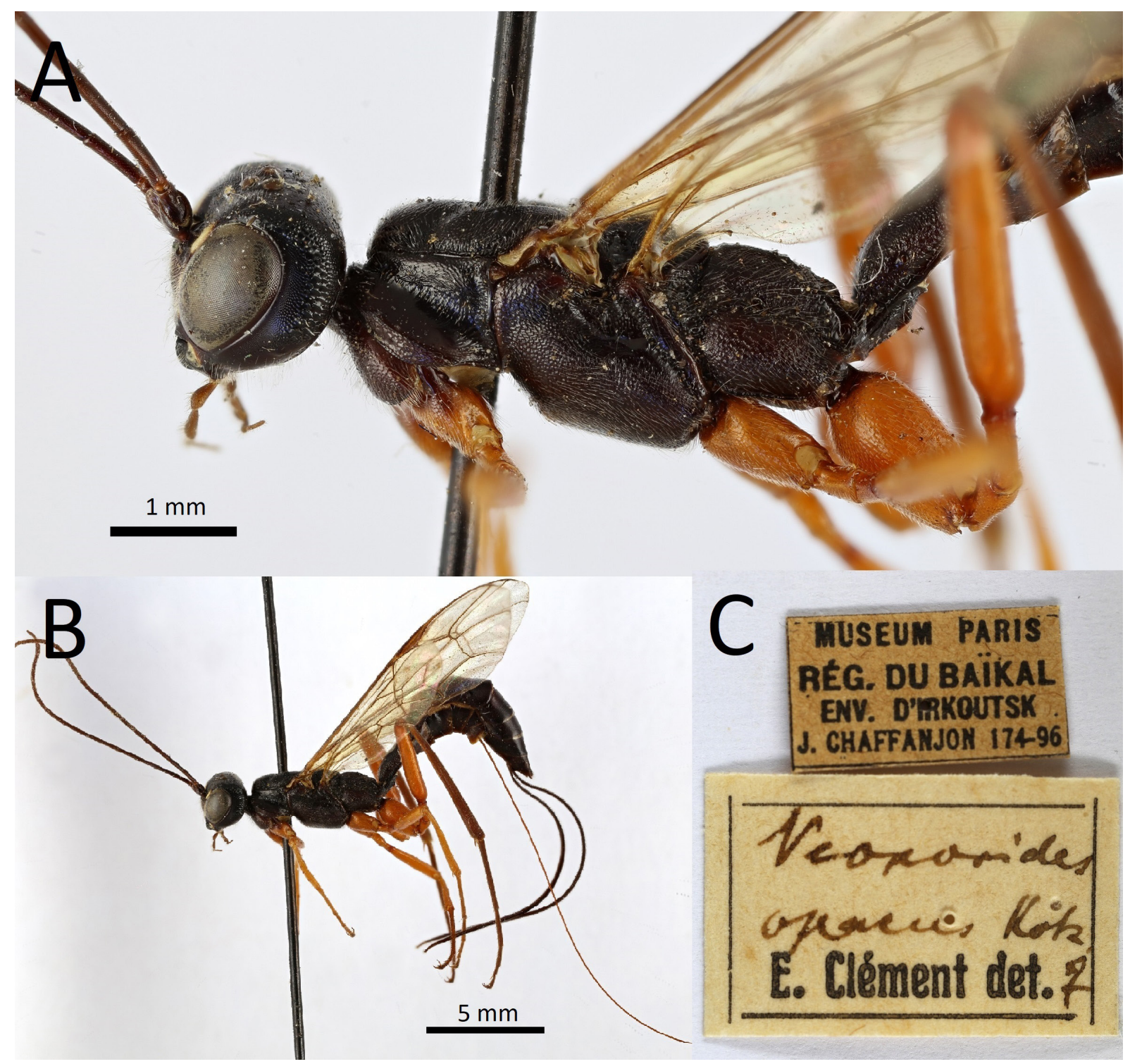

Fig. 8. Neoxorides opacus (Kokujev, 1903) stat. rev., $q$, neotype (MNHN). A. Head and mesosoma, lateral view. B. Habitus, lateral view. C. Labels. Photos: Claire Villemant. 


\section{Remarks}

The status of $N$. opacus has historically been subject to different interpretations. Clément (1938) treated it as a valid species based on the original description and proposed $N$. kissi to be a junior synonym, but Oehlke (1966) put $N$. opacus and $N$. kissi in synonomy with $N$. nitens, referring to a couple of morphologically deviant females, one from Germany and one from Southern Europe. However, he qualified the synonymy with a question mark and stated that he was doubtful whether $N$. opacus and the apparently conspecific $N$. kissi are to be regarded as varieties of $N$. nitens or as valid species. The holotype of N. opacus, a single female collected in Irkutsk in the Siberian Far East (Kokujev 1903), is lost (Townes et al. 1960), and there is no known additional material of the species determined by Kokujev (Andrey Khalaim, ZIN, pers. com.). However, in the MNHN, there is a specimen referred to by Clément (1938). This specimen was collected in the vicinity of Irkutsk by the French explorer Jean Chaffanjon (spelled "Chaffaniou" in Clément 1938) and corresponds to the interpretation of N. opacus presented in this study. As this specimen originates from the type locality, it is hereby designated as neotype (Fig. 8A-C). One of the two female specimens listed by Oehlke (1966) as "N. nitens var. opacus", the one in the Förster collection in Berlin, has been studied and it is in agreement with the interpretation of $N$. opacus presented here. The other, collected in Sachsen, Germany, seems to be lost (Jutta Helbig, ZMHB, pers. com.). The female lectotype of $N$. kissi and one quite badly damaged male paralectotype in the HNHM, collected in Ferenczfalva, Hungary (now Văliug, Romania) also fits the interpretation of $N$. opacus as defined in this study and the synonymy between N. kissi and N. opacus, previously proposed by Clément (1938), is hereby confirmed.

\section{DNA barcode}

The barcode of this species is separated from its closest barcode (in N. collaris) by $7.0 \%$ p-distance. The sequence is available on GenBank under accession number: MT072692 (SK19_38).

\section{Neoxorides striatus Johansson sp. nov. urn:1sid:zoobank.org:act:E08054F6-B6CC-41A1-8F84-5D221C781D6D}

Figs $1 \mathrm{~A}-\mathrm{C}, 9 \mathrm{~B}, \mathrm{E}, \mathrm{H}$

\section{Diagnosis}

Neoxorides striatus sp. nov. (Fig. 1A) is similar to N. collaris and N. montanus regarding colour and shape, and is intermediate between those species. The face of the male is usually narrower (Fig. 9H) in comparison with the other two species (Fig. 9G). Furthermore, the frons is weakly transversely striate in N. striatus sp. nov. (Fig. 1B) but more evenly shagreened in N. collaris and N. montanus, and the mesopleural furrow usually has more distinct transverse carinae (Fig. 1C, frequently almost as in Fig. 6F). Neoxorides striatus sp. nov. is also distinguished from N. montanus by the usually slightly shorter first tergite in the female (Fig. 9E) (overlap exists), the orange mid coxae in the female, the narrower white line on the sides of the pronotum and the smaller white spots along the inner orbits above the antennal scrobes. The latter character is more evident in females, but the marks are usually shorter and narrower in males with the inner margins concave, while the inner margins are usually convex in the male of N. montanus. From N. collaris it is also distinguished by the longer first tergite (Fig. 9E) and the usually shorter/wider white spots along the inner orbits (Fig. 9B).

\section{Etymology}

The weak striation of the frons in combination with the striate sides of pronotum and transverse carination of the mesopleural furrow is diagnostic. 


\section{Material examined}

\section{Holotype}

GERMANY • ○’; Bavaria, Nürnberg; 8 May 2001; R. Bauer leg.; ZSM BC ZSM HYM07485 (Fig. 1A-C).
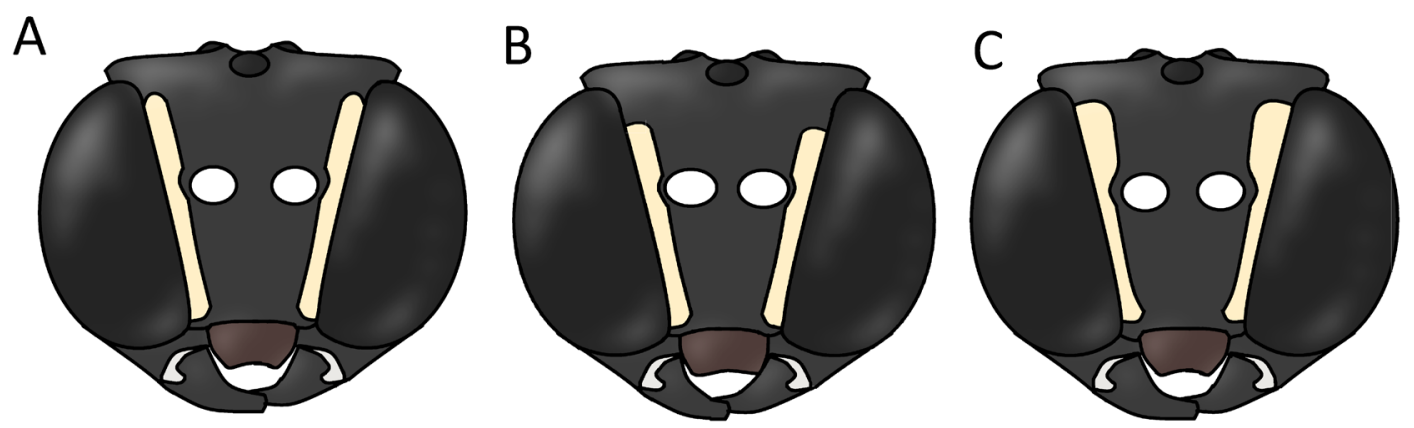

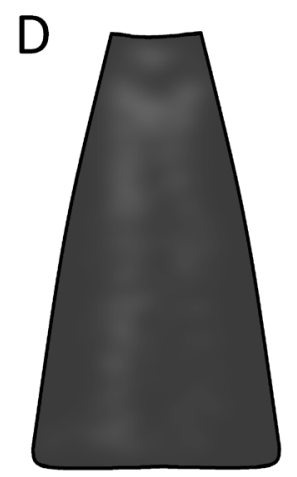

$\mathrm{E}$
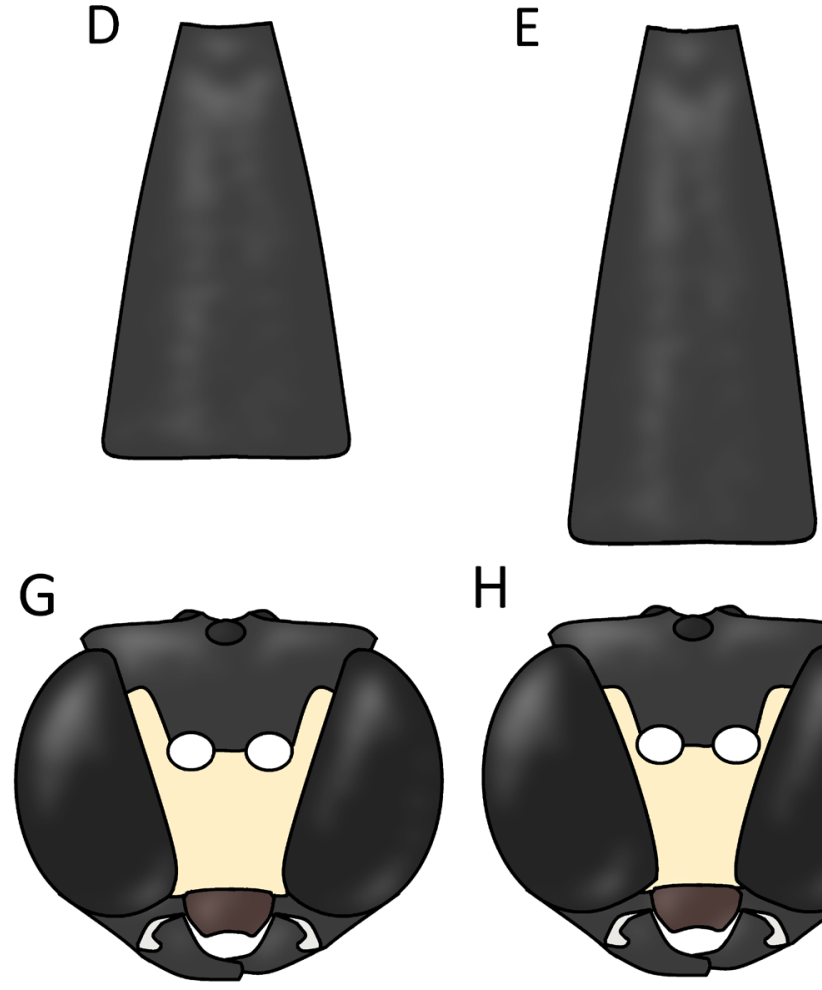

$\mathrm{H}$

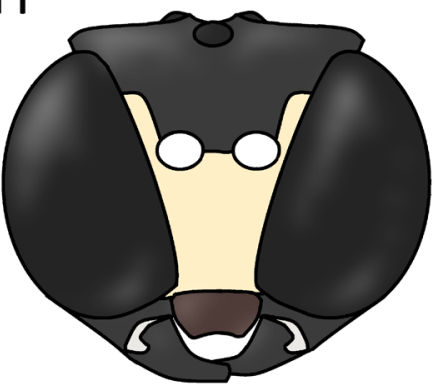

$\mathrm{F}$

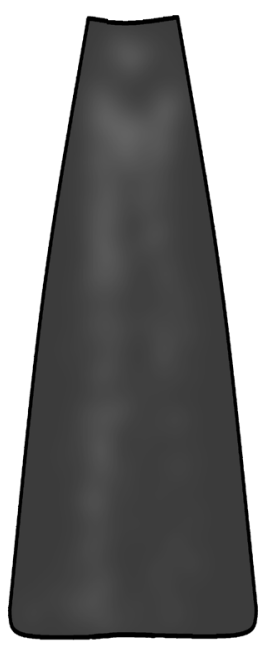

Fig. 9. A-C. $q$, generalized shape of head and colouration of face, anterior view. A. Neoxorides collaris (Gravenhorst, 1829). B. N. striatus Johansson sp. nov. (lectotype NHRS-HEVA000011623). C. N. montanus (Oehlke, 1966). D-F. \&, generalized shape of first tergite, dorsal view. D. N. collaris. E. N. striatus Johansson sp. nov. (lectotype NHRS-HEVA000011623). F. N. montanus. G-H. Ō, generalized shape of head and colouration of face in anterior view. G. N. montanus. H. N. striatus Johansson sp. nov. (paratype NHRS-HEVA000011622). 


\section{Paratypes}

SWEDEN • 1 †; Uppland, Norrtälje, Väddö; probably 1890-1895; G.A. Ringselle leg. (1868-1944); MZLU 754 2019 • 1 q; Ångermanland, Bjurholm, Käringbergets ekopark; 30 May-30 Jul. 2011; M. Larshagen/Sveaskog leg.; NHRS-HEVA000011623 • 1 ơ; Hälsingland, Ramsjö, Ensjölokarna; 30 May-28 Jun. 2002; window trap; L.-O. Wikars leg.; NHRS-HEVA000011622 • 5 + ; coll. Marklin (1777-1857); UPSZEN 153034 to $153038 \cdot 5 \hat{\jmath}$; ; same collection data as for preceding; UPSZEN

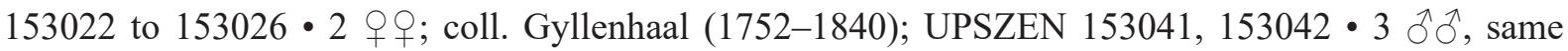
collection data as for preceding; UPSZEN 153031 to $153033 \bullet 1$ q ; coll. Haeffner (active 1800-1815);

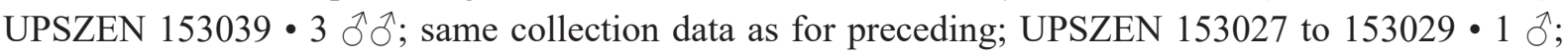
coll. Stenhammar (1783-1866); UPSZEN 153030 • 1 क ; Småland; C.H. Boheman leg. (1796-1868); NHRS-HEVA000011613 • 1 § ; same collection data as for preceding; NHRS-HEVA000011599・1 ; Stockholm; 19 $9^{\text {th }}$ century; NHRS-HEVA000011612 • 1 \%; "Hlm" [Stockholm]; C.H. Boheman leg. (1796-1868); NHRS-HEVA000011611 • 1 O ; Östergötland; $19^{\text {th }}$ century; NHRS-HEVA000011607 • $1 \partial^{\lambda}$; Uppland; $19^{\text {th }}$ century; NHRS-HEVA000011612 • 1 क ; Östergötland, Norrköping, Kimstad; 15 Jun. (year unknown); probably E. Haglund leg. (1837-1901); NHRS-HEVA000011600 • 1 क; Uppland, Uppsala, Vassunda; probably 1905-1910; O. Lundblad leg. (1890-1970); NHRS-HEVA000011598 • 1 ठ’; Östergötland, Linköping, Sankt Lars, på Gärdesgård (on wooden fence); 10 Jun. 1914; H. Nordenström leg.; NHRS-HEVA000011597 • 1 ô; Östergötland, Norrköping, Kimstad; 23 Jun. (year unknown); probably E. Haglund leg. (1837-1901); NHRS-HEVA000011596 • 1 đ̂; Halland, Kungsbacka, Särö; 23 Jun. (year unknown); N. Westring leg. (1798-1882); NHRS-HEVA000011595 • 1 \%; Östergötland (green rhomb); NHRS-HEVA000011594 • 1 §̊; "Hlm” [Stockholm]; C.H. Boheman leg. (1796-1868); NHRS-HEVA000011593.

FINLAND - 1 q; Åland, Eckerö; 1939; W. Hellén leg.; MZH 355 (http://id.luomus.fi/GP.110132) • 1 ô; Varsinais-Suomi, Lohja, Kouvola Village; 7-10 Jun. 1910; R. Frey leg.; MZH 339 (http://id.luomus.fi/GP.110106) • 1 \%; Varsinais-Suomi, Turku, Ispois (Ispoinen); E. Reuter leg.; MZH (http://id.luomus.fi/GP.110107) • 1 §’; Satakunta, Loimaa; A. Merisuo leg.; MZH (http://id.luomus.fi/GP.110117) • 1 o; Etelä-Häme, Hattula; L. von Essen leg.; MZH 4184 (http://id.luomus.fi/GP.110119) • 1 क; Etelä-Häme, Hattula; A. Wegelius leg.; MZH 574 (http://id.luomus.fi/GP.110127) • 1 o+; Etelä-Häme, Pirkkala; T. Grönblom leg.; MZH 589 (http://id.luomus.fi/GP.110116) • 1 ô; Etelä-Häme, Palkäne; W. Hellén leg.; MZH 842 (http://id.luomus.fi/GP.110133)・ 1 ठ̊; Pohjois-Karjala, Nurmes; 17 Jun. 1939; A. Saarinen leg.; MZH (http://id.luomus.fi/GP.110115) • 1 \%; Keski-Pohjanmaa, Haapavesi; unspecified date but probably 1890s;

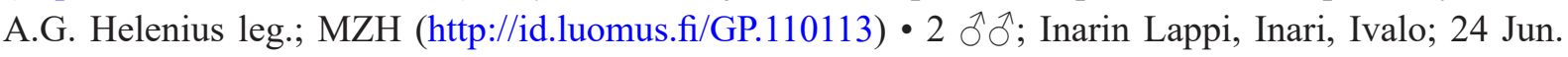
1930; R. Frey leg.; MZH 181, 186 (http://id.luomus.fi/GP.110121, http://id.luomus.fi/GP.110117) • 1 ; Inarin Lappi, Inari, Ivalo; 24 Jun. 1937; W. Hellén leg.; MZH 1178 (http://id.luomus.fi/GP.110130) • 1 †; Inarin Lappi, Inari, Ivalo; 25 Jun. 1937; W. Hellén leg.; MZH 1254 (http://id.luomus.fi/GP.110124) - 2 ठ̊̄; Inarin Lappi, Inari, Ivalo; W. Hellén leg.; MZH 127 (http://id.luomus.fi/GP.110128; http://id.luomus.fi/GP.110129).

UKRAINE 1 đ; ; Ivano-Frankivsk Region, Bogorodchany District, Mochary, 5 km NE of Bogorodchany; 300-320 m; 28 Apr. 2018; O. Varga leg.; mixed forest, sweep netting; NHRS-HEVA000011621.

GERMANY • 1 đ; Bavaria, Nürnberg; 16 May 2001; R. Bauer leg.; ZSM BC ZSM HYM07484 • 1 đ; Oberbayern, Ammergauer Alpen, Oberammergau; 16 Jul. 2017; 850 m; M. Riedel leg.; MR.

EUROPE • 1 क; “1881-93”; coll. Buchecker; probably of Central European origin; NHMUK. 


\section{Description}

Fore wing length 6-14 mm. Antenna in both sexes with 28-36 flagellomeres. First to fourth flagellomere about 4.5-5.0 times as long as wide. Central flagellomeres stout, about 1.5-1.7 times as long as wide. Subapical flagellomeres approximately $0.8-1.0$ times as long as wide. Temple slightly widened behind eyes in dorsal view, with coarse scale-like structure following outer and upper margin of compound eye. Frons between antennal scrobes and central ocellus with weak transverse striation (Fig. 1B). Face shagreened, frequently with weak transverse striation in lower half. Head dorsally, behind compound eyes, with rather indistinct punctures on a shagreened background. Inner orbits strongly converging. Face in male narrower than in $N$. collaris and $N$. montanus (Figs 1B, 9H). Face below antennal sockets quite smooth with indication of transverse striae in lower part. Mandible chisel-shaped, with sides converging as in N. collaris. Malar space short, about 0.1 times as wide as mandibular base. Wing membrane clear. Pronotum centrally unmodified, not raised as in $N$. nitens. Sides of pronotum centrally with distinct striae, which extends upwards/backwards to upper part (as in Fig. 6G). Striae often more distinct and larger than in N. montanus. Mesosternum and mesopleuron shagreened with quite dense but clearly discernible punctures, slightly denser and more distinct than in N. collaris and N. montanus. Mesopleuron in front of speculum with weak striae (Fig. 1C). Mesopleural furrow with distinct transverse carinae (Fig. 1C). Mesoscutum shagreened with indistinct punctures, centrally transversely strigose. Notauli deeply impressed, dividing the mesoscutum into three lobes. Scutellum with indistinct punctures on a shagreened background. Propodeum basally weakly aciculate (as in Fig. 6A). Submetapleural carinae complete. First tergite in female 2.0-2.3 times as long as wide (Fig. 9E), in male more variable, about 2.5-3.5 times as long as wide. Sclerotised section of first sternite with a raised keel-like projection centrally often with weak transverse ridges. First to third tergite with transverse rugulose striation that sometimes extends to sides. Male parameres usually more strongly sclerotized, as in typical N. collaris.

\section{Colouration}

Body black. Inner orbit in female with a white line which is about two times as long as wide above the antennal scrobes. Face in male entirely white. Spot below the occipital carina centrally white. The white line on the sides of pronotum is very narrow in both sexes and usually at most about $1 / 3$ as wide as the width of the fore femur, missing in small specimens. Tegulae and palpi white. Antennae black or brown. Wing veins and pterostigma testaceous. Coxae in female orange. Mid coxae in large males with large yellow spot that covers most of the outer side or a smaller yellow spot, in smaller males coxae entirely orange. Trochanter and trochantelli yellowish. Legs orange, hind tibia and hind- and mid-tarsi infuscate. Fore and mid femur and tibia sometimes yellow anteriorly.

\section{Ecology}

No host is known for Neoxorides striatus sp. nov. Most records seem to stem from pristine coniferous forests. The available records indicate that the period of flight is June and July in northern Europe.

\section{Distribution and status in Sweden}

Only a few recent records. All present localities consist of relatively large fragments of primeval forests. Numerous old specimens from the $19^{\text {th }}$ century in collections from Sweden and Finland indicates a strong decline in numbers during the last century. Ha, Hs, Sm, Up, Ån, Ög.

\section{DNA barcode}

The barcodes of this species are separated from their closest barcode (in N. montanus) by $4.6 \%$ p-distance. The sequences are stored on BOLD under accession numbers: FBICA170-11 (BC ZSM HYM 07485), FBICA169-11 (BC ZSM HYM 07484). 
Neoxorides varipes (Holmgren, 1860)

Fig. 5A-B

Xorides varipes Holmgren, 1860: 66.

Xorides collaris ab. picicoxis Hellén, 1915: 20 syn. nov.

Neoxorides varipes - Clément 1938: 519. — Oehlke 1966: 891. — Kasparyan 1981: 94. — Varga 2015: 4-5, fig. 2.

Neoxorides variipes - Clément 1938: 517.

Neoxorides varpies - Kanders 2009: 9.

Xorides variipes - Dalla Torre 1901-1902: 382. — Schmiedeknecht 1908: 1369.

\section{Diagnosis}

Fore wing length 6-10 mm. Neoxorides varipes is distinguished from other species of Neoxorides in the Western Palaearctic by the virtually impunctate and strongly shagreened mesosternum and mesopleuron, the weakly reticulate sides of the pronotum (Fig. 5B) and the infuscate hind coxae. The ovipositor in the female is relatively short, about as long as the metasoma minus the first and second tergite. The female has all the coxae infuscate, while the mid and fore coxae in the male are mainly whitish. The white spots along the inner orbits above antennal sockets are shorter than in N. collaris and N. montanus (Fig. 5A). The male has the propleuron with large whitish spots basally, while it usually is infuscate in $N$. collaris and N. montanus. Four small females from Northern Sweden have all the legs infuscate and the anterior side of the mid and fore tibia yellowish. Apart from the darker colour and smaller size, we have found no reliable distinguishing character between these forms and they are treated here as a small northern variety.

\section{Material examined}

Lectotype

SWEDEN • ${ }^{\top}$; NHRS.

Other material

SWEDEN • 4 ㅇ, 4 ふ̊ ô; JH, NJ, UPSZ, NHRS.

FINLAND・ 4 + $;$; MZH.

NORWAY • 1 q; MR.

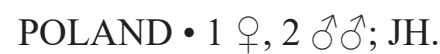

UKRAINE $・ 2$ +, 1 §; OV.

\section{Ecology}

Neoxorides varipes is probably connected to cerambycids feeding on conifers. Collected in relatively large numbers on logs of Picea abies and Abies alba Mill. (Varga 2015; O. Varga pers. com.). It has been reared from branches containing Callidium aeneum (De Geer, 1775) and Obrium brunneum (Fabricius, 1792) (J. Hilszczański pers. com.).

\section{Distribution and status in Sweden}

Neoxorides varipes is a very rare species in Sweden with only a few known records. It is an exclusive inhabitant of pristine boreal forests rich in dead wood in the northern part of the country. Vb, Ås. 


\section{Remarks}

Due to its rarity, the distinction between $N$. varipes and other species of the genus, primarily N. collaris, has mainly relied upon the typical colouration of the hind coxae. There are, however, some additional characters used in the key to species. Two females labelled as N. collaris ab. picicoxis (Hellén, 1915) syn. nov. in the MZH were studied by the first author and they both represent pale specimens of $N$. varipes.

\section{DNA barcode}

No fresh material suitable for barcoding was available to us.

\section{Discussion}

The results from barcoding and the thorough study of the morphological differences provided here show that previous taxonomical work on the genus in the Western Palaearctic has partly failed to properly define the species involved. This could be explained by several factors, such as the species being relatively rarely collected and the misinterpretation of certain characters and their importance when it comes to species delimitations based on morphology. By integrating morphological data with the molecular barcode, we could here put species delimitations and the suggestion of diagnostic characters on a robust foundation, which will allow reliable identification of the species in the future. In contrast to other groups of ichneumonid wasps for which the barcode region was not informative for many species (Klopfstein 2014), which was at least partly caused by Wolbachia Hertig \& Wolbach, 1924 endosymbionts (Klopfstein et al. 2016), we found large interspecific distances (at least 4.6\%) and solid barcoding gaps in all examined species of Neoxorides. Even though the latter might decrease somewhat once specimens from a larger part of their distribution range are sequenced (Bergsten et al. 2012), the marker has thus proven very useful in this genus, at the very least on the country scale.

The results presented in this study indicate that species of Neoxorides possibly show a higher degree of ecological specialization regarding hosts and preferred habitat than previously appreciated, making them potentially useful in a conservation context. On The 2019 Red List of Finnish Species (Hyvärinen et al. 2019), N. collaris is classified as EN (Endangered), N. varipes as RE (Regionally Extinct) and $N$. montanus as NT (Near Threatened). The assessment of the situation in Sweden is perhaps more conservative, given the scarcity of data, and $N$. varipes is classified as NT (Near Threatened) in the upcoming version (2020). Note that N. striatus sp. nov. was not assessed for the Red List. The Swedish classifications are based upon the assumptions of quite a large estimated number of unknown records and common and widespread hosts (Tetropium Kirby, 1837, Phymatodes Mulsant, 1839, Rhagium Fabricius, 1775, Xylotrechus Chevrolat, 1860, etc.). However, specimens of Neoxorides are quite rare in historical collections, and most modern records stem from surveys of saproxylix insects in areas which are to be regarded as forest biodiversity hotspots. For example, the locality Ensjölokarna in Hälsingland (Fig. 10), one of a few remaining fragments of primeval forest (Wikars 2003) in Central Sweden, houses as least three of the species connected to coniferous forests: $N$. collaris, $N$. montanus and $N$. striatus sp. nov. Very little is known about the occurrence of Neoxorides species in biologically impoverished tree plantations, which constitute a growing part of the forested areas in Sweden (Claesson et al. 2015). This means that coleopterists and researchers that specialize in saproxylic insects can contribute greatly to the knowledge of these parasitoids by documenting rearing records and recording specimens collected by traps, material that would usually be disposed of. This also reflects another benefit of the work presented here, as correct taxonomy actually enables the unveiling of ecological strategies that otherwise would be obscured by wider and invalid species concepts.

Fundamental taxonomic work of the kind presented here is a prerequisite for all other studies involving the species level, including population and ecosystem dynamics. Neoxorides and other genera with similar ecology (parasitoids on well-known saproxylic hosts), i.e., Xorides Latreille, 1809, Odontocolon 
Cushman, 1942, Ischnoceros Gravenhorst, 1829, etc., are well suited for studies of boreal forest ecosystems, where the parasitoid level at an early stage can provide information on the stability of the ecosystem (Shaw \& Hochberg 2001; Hilszczański et al. 2005; Shaw 2006). Sweden still harbors a considerable proportion of the remaining high conservation value forests of Northwestern Europe, and the Nordic countries have a responsibility when it comes to preserving these ecosystems from a European perspective. This calls for an increase in the study of forest ecosystem dynamics also including relatively easily identifiable parasitoids like the ones found in the subfamilies Xoridinae Schuckard, 1840 and Poemeniinae. This highlights the need for easily accessible identification keys based on correct taxonomy and, by extension, the need for basic taxonomic studies as a foundation for any ecological studies based on species populations or population dynamics involving the parasitiod level.

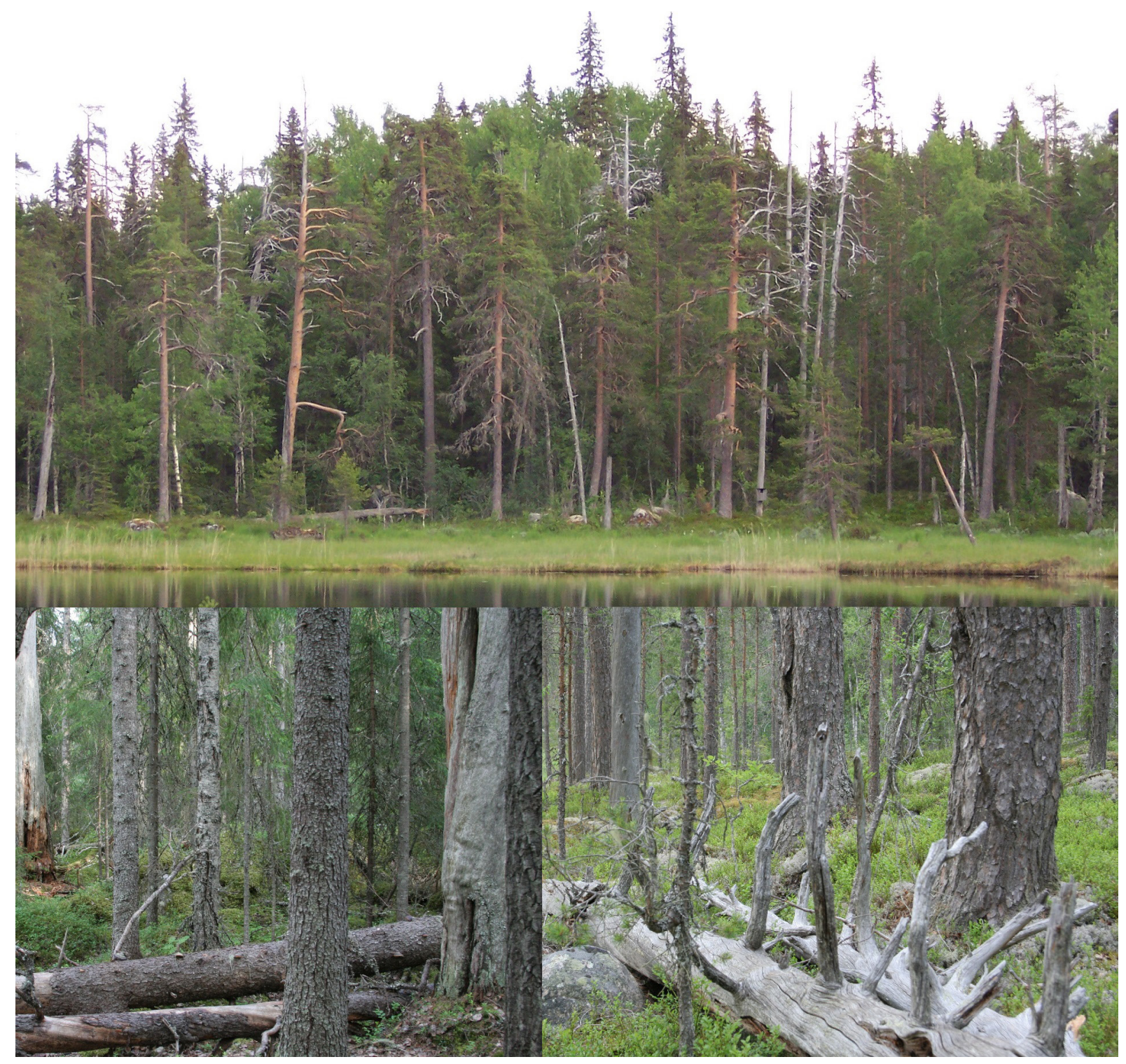

Fig. 10. Ensjölokarna in the province of Hälsingland, Sweden. One of a few fragments of primeval forest that remains in Central Sweden. Habitat of Nexorides collaris (Gravenhorst, 1829), N. montanus (Oehlke, 1966) and N. striatus Johansson sp. nov. Photo: Maria von Hofsten and Länsstyrelsen i Gävleborg. 


\section{Acknowledgements}

We would like to thank Stefan Schmidt at the ZSM for kindly sharing some of the barcodes used in this study and the assistance with the type designation of Neoxorides striatus sp. nov. Jutta Helbig and Lukas Kirschey at ZMHB tracked down and photographed the female $N$. opacus in the Förster collection. Zoltán Vas and Tamás Németh at HNHM arranged for the study of the type material of $N$. kissi housed in their collections. Juho Paukkuen at the MZH arranged a loan of Finnish Neoxorides. We thank Alexander Berg for the excellent photos used in this publication. Håkan Andersson, Linköping, donated his material of Darwin wasps collected with window traps throughout the years. We acknowledge Hege Vårdal (NHRS), Mats Jonsell (SLU), Hans Mejlon (UPSZ) and Rune Bygebjerg (MZLU) for providing access to their respective collections. Mattias Forshage contributed with his knowledge on old entomologists and their primary collecting grounds. Andrey Khalaim (ZIN) helped with searching the collections in St. Petersburg for potential additional specimens of N. opacus. We thank Claire Villemant at the MNHN for the photos of the neotype and Claire Villemant and William Penigot for helping out with the detection and designation of the neotype of N. opacus in MNHN. Matthias Riedel, Olexandr Varga, Lars-Ove Wikars and Jacek Hilszczański kindly provided specimens for study from their own private collections. Olexander Varga also kindly shared some pictures of the holotype and one female paratype of $N$. montanus. We also thank Marek Wanat at the NMWU for providing high resolution photos of the lectotype of $N$. collaris. Mark Shaw and Jacek Hilszczański provided valuable suggestions that improved the quality of the manuscript. Gavin Broad arranged for the study of the Neoxorides in the NHMUK and Roger Mugerwa Pettersson (SLU) detected some rare literature. Maria von Hofsten and Andreas Wedman at the county administrative board in Gävleborg shared the pictures of Ensjölokarna.

\section{References}

Bergsten J., Bilton D.T., Fujisawa T., Elliott M., Monaghan M.T., Balke M., Hendrich L., Geijer J., Herrmann J., Foster G.N., Ribera I., Nilsson A.N., Barraclough T.G. \& Vogler A.P. 2012. The effect of geographical scale of sampling on DNA barcoding. Systematic Biology 61: 851-869. https://doi.org/10.1093/sysbio/sys037

Broad G.R., Shaw M.R. \& Fitton M.G. 2018. Ichneumonid wasps (Hymenoptera: Ichneumonidae): their classification and biology. Handbooks for the identification of British Insects Vol 7. Part 12. Royal Entomological Society and Field Studies Council.

Claesson S., Duvemo K., Lundström A. \& Wikberg P-E. 2015. Skogliga konsekvensanalyser 2015SKA 15. Skogsstyrelsen och SLU, Jönköping.

Clément E. 1938. Opuscula Hymenopterologica IV. Die paläarktischen Arten der Pimplinentribus Ischnocerini, Odontomerini, Neoxoridini und Xylomini (Xoridini Schm.). Festschrift zum 60. Geburtstag Prof. Dr. Embrik Strand 4: 502-569.

Dalla Torre C.G. 1901-1902 Catalogus Hymenopterorum, hucusque descriptorum systematicus et synonymicus. Vol 3. Trigonalidae, Megalyridae, Stephanidae, Ichneumonidae, Agriotypidae, Evaniidae, Pelecinidae. Sumptibus Guilelmi Engelmann, Lipsiae [Leipzig]. https://doi.org/10.5962/bhl.title.10348

Folmer O., Black M., Hoeh W., Lutz R. \& Vrijenhoek R. 1994. DNA primers for amplification of mitochondrial cytochrome c oxidase subunit I from diverse metazoan invertebrates. Molecular Marine Biology and Biotechnology 3 (5): 294-299.

Gravenhorst J.L.C. 1829. Ichneumonologia Europaea. Pars III. Vratislaviae [Wroclaw]. https://doi.org/10.5962/bhl.title.11531

Haupt H. 1917. Neues und Ergaenzendes zur Gruppe der Xoridinen. (Fam. Ichneumonidae, III. Subf. Pimplinae, 3. Tribus Xoridini). Mitteilungen der Entomologischen Gesellschaft Halle 11: 77-87.

Hellén W. 1915. Beiträge zur Kenntnis der Ichneumoniden Finlands I. Subfamily Pimplinae. Acta Societatis pro Fauna et Flora Fennica 40 (6): 1-89. 
Hilszczański J., Gibb H., Hjältén J., Atlegrim O., Johansson T., Pettersson R.B., Ball J.P. \& Danell K. 2005. Parasitoids (Hymenoptera, Ichneumonoidea) of saproxylic beetles are affected by forest successional stage and dead wood characteristics in boreal spruce forest. Biological Conservation 126: 456-464. https://doi.org/10.1016/j.biocon.2005.06.026

Holmgren A.E. 1860. Försök till uppställning och beskrifning af Sveriges Ichneumonider. Tredje Serien. Fam. Pimplariae. (Monographia Pimplariarum Sueciae). Kongliga Svenska Vetenskapsakademiens Handlingar (B) 3 (10), Stockholm.

Horstmann K. 1988. Revision der von Fahringer beschriebenen westpaläarktischen IchneumonidenArten (Hymenoptera). Zeitschrift der Arbeitsgemeinschaft Österreichischer Entomologen 40 (1): 14-22.

Hyvärinen E., Juslén A., Kemppainen E., Uddström A. \& Liukko U.-M. (eds). 2019. Suomen lajien uhanalaisuus - Punainen kirja 2019. Ympäristöministeriö \& Suomen ympäristökeskus, Helsinki.

Jałoszyński P. \& Wanat M. 2014. Johann Ludwig Christian Gravenhorst, the first director of the Museum of Natural History, University of Wrocław, and his collection of Ichneumonidae. Genus 25 (4): 583-599.

Kanders J. 2009. Swedish Species of the Poemeniinae (Hymenoptera: Ichneumonidae). Degree project in Biology, Master of science, Biology Education Centre, Uppsala University, and Swedish Museum of Natural History, Stockholm.

Kasparyan D.R. 1981. A guide to the insects of the European part of the USSR. Hymenoptera, Ichneumonidae. Subfamily Pimplinae (Ephialtinae). [In Russian.] Opredeliteli Faune SSSR 129: 41-97.

Kenis M. \& Hilszczański J. 2004. Natural enemies of Cerambycidae and Buprestidae infesting living trees. In: Lieutier F., Day K.R., Battisti A., Grégoire J.C. \& Evans H.F (eds) Bark and Wood Boring Insects in Living Trees: 475-494. Springer, Dordrecht. https://doi.org/10.1007/1-4020-2241-7_21

Klopfstein S. 2014. Revision of the Western Palaearctic Diplazontinae (Hymenoptera, Ichneumonidae). Zootaxa 3801 (1): 1-143. https://doi.org/10.11646/zootaxa.3801.1.1

Klopfstein S., Kropf C. \& Baur H. 2016. Wolbachia endosymbionts distort DNA barcoding in the parasitoid wasp genus Diplazon (Hymenoptera: Ichneumonidae). Zoological Journal of the Linnean Society 177 (3): 541-557. https://doi.org/10.1111/zoj.12380

Klopfstein S., Santos B.F., Shaw M.R., Alvarado M., Bennett A.M.R., Dal Pos D., Giannotta M., Herrera Florez A.F., Karlsson D., Khalaim A.I., Lima A.R., Miko I., Sääksjärvi I.E., Shimizu S., Spasojevic T., van Noort S., Vilhelmsen L. \& Broad G. 2019. Darwin wasps: a new name heralds renewed efforts to unravel the evolutionary history of Ichneumonidae. Entomological Communications 1: ec01006. https://doi.org/10.37486/2675-1305.ec01006

Kokujev N.R. 1903. Hymenoptera asiatica nova. Russkoe Entomologicheskoye Obozreniye 3: 285-288.

Kolarov J.A. 1997. Fauna Bulgarica vol. 25. Hymenoptera, Ichneumonidae. Part I. Pimplinae, Xoridinae, Acaenitinae, Collyriinae, Pensoft Publishers, Sofia.

Kumar S., Stecher G., Li M., Knyaz C. \& Tamura K. 2018. MEGA X: Molecular Evolutionary Genetics Analysis across computing platforms. Molecular Biology and Evolution 35: 1547-1549.

https://doi.org/10.1093/molbev/msy096

Oehlke J. 1966. Die westpalaearktischen Arten der Tribus Poemeniini (Hymenoptera: Ichneumonidae), Beiträge zur Entomologie 15 (1965): 881-892.

Ratzeburg J.T.C. 1848. Die Ichneumonen der Forstinsecten in forstlicher und entomologischer Beziehung. Zweiter Band. Berlin.

Ronquist F., Teslenko M., Van der Mark P., Ayres D.L., Darling A., Höhna S., Larget B., Liu L., Suchard M.A. \& Huelsenbeck J.P. 2012. MrBayes 3.2: Efficient Bayesian phylogenetic inference and model choice across a large model space. Systematic Biology 61: 539-542.

https://doi.org/10.1093/sysbio/sys029 
Ronquist F., Forshage M., Häggqvist S., Karlsson D., Hovmöller R., Bergsten J., Holston K., Britton T., Abenius J., Andersson B., Neerup Buhl P., Coulianos C.-C., Fjellberg A., Gertsson C.-A., Hellqvist S., Jaschhof M., Kjærandsen J., Klopfstein S., Kobro S., Liston A., Meier R., Pollet M., Prous M., Riedel M., Roháček J., Schuppenhauer M., Stigenberg J., Struwe I., Taeger A., Ulefors S.O., Varga O., Withers P. \& Gärdenfors U. 2020. Completing Linnaeus's inventory of the Swedish insect fauna: only 5,000 species left? PLoS ONE, in print. https://doi.org/10.1371/journal.pone.0228561

Schimitschek E. 1935. Forstschädlingsauftreten in Osterreich 1927 bis 1933. (Fortsetzung). Centralblatt für das Gesamte Forstwesen 61 (7/8): 134-150.

Schmiedeknecht O. 1907. Hymenoptera. Fam. Ichneumonidae. Subfamilie Pimplinae. Genera Insectorum 62, L. Desmet-Verteneuil, Bruxelles [Brussels].

Schmiedeknecht O. 1908. Opuscula ichneumonologica fascicule 15: 1367-1369. Blankenburg i Thür. https://doi.org/10.5962/bhl.title.10486

Shaw M.R. 2006. Habitat considerations for parasitic wasps (Hymenoptera). Journal of Insect Conservation (2006) 10: 117-127. https://doi.org/10.1007/s10841-006-6288-1

Shaw M.R. \& Hochberg M. 2001. The neglect of parasitic Hymenoptera in insect conservation strategies: the British fauna as a prime example. Journal of Insect Conservation 5 (4): 253-263. https://doi.org/10.1023/A:1013393229923

Sheng M.L. 1998. Studies on the genus Neoxorides from northeastern China (Hymenoptera: Ichneumonidae). Acta Zootaxonomica Sinica 23 (2): 201-204.

Townes H.K., Townes M., Walley G.S., Walkley L., Habeck D \& Townes G. 1960. Ichneumon-flies of American north of Mexico: 2. subfamily Ephialtinae, Xoridinae, Acaenitinae. United States National Museum Bulletin 216 (2): 1-676. https://doi.org/10.5479/si.03629236.216.1-2

Uchida T. 1928. Dritter Beitrag zur Ichneumoniden-Fauna Japans. Journal of the Faculty of Agriculture, Hokkaido University 25: 1-115.

Ulbricht A. 1911. Ichneumonidenstudien. Archiv für Naturgeschichte 77 (2): 144-152.

Varga O. 2015. A review of the subfamily Poemeniinae Narayanan \& Lal, 1953 (Hymenoptera, Ichneumonidae) from Carpathians. Journal of Insect Biodiversity 3 (7): 1-14.

https://doi.org/10.12976/jib/2015.3.7

Wikars L.-O. 2003. Vedinsekter $i$ urskogsreservatet Ensjölokarna i Nordvästra Hälsingland. Länsstyrelsen i Gävleborgs län.

Yu D.S.K., van Achterberg C. \& Horstmann K. 2016. Taxapad 2016, Ichneumonoidea 2015 (Biological and taxonomical information), Taxapad Interactive Catalogue Database on flash-drive. Nepean, Ottawa. Available from https://www.catalogueoflife.org/col/details/database/id/68 [accessed 29 Jun. 2020].

Manuscript received: 25 February 2020

Manuscript accepted: 19 May 2020

Published on: 6 July 2020

Topic editor: Gavin Broad and Nesrine Akkari

Desk editor: Radka Rosenbaumová

Printed versions of all papers are also deposited in the libraries of the institutes that are members of the EJT consortium: Muséum national d'histoire naturelle, Paris, France; Meise Botanic Garden, Belgium; Royal Museum for Central Africa, Tervuren, Belgium; Royal Belgian Institute of Natural Sciences, Brussels, Belgium; Natural History Museum of Denmark, Copenhagen, Denmark; Naturalis Biodiversity Center, Leiden, the Netherlands; Museo Nacional de Ciencias Naturales-CSIC, Madrid, Spain; Real Jardín Botánico de Madrid CSIC, Spain; Zoological Research Museum Alexander Koenig, Bonn, Germany; National Museum, Prague, Czech Republic. 